\title{
Regional Differences in Glial-derived Factors that Promote Dendritic Outgrowth from Mouse Cortical Neurons in vitro
}

\author{
Peter D. Le Roux and Thomas A. Reh \\ Departments of Neurosurgery and Biological Structure, University of Washington, Seattle, Washington 98195
}

To determine whether glia trom different CNS regions differ in their ability to support axons or dendrites, embryonic (E18) mouse cortical neurons were cocultured with early postnatal (P4) rat astroglial derived from cortex, retina, olfactory bulb, mesencephalon, striatum, and spinal cord. After $5 \mathrm{~d}$ in vitro, axon and dendrite outgrowth from isolated neurons was quantified with double-labeling immunohistochemical techniques. Whereas axonal growth was similar on the various monolayers, total primary dendritic outgrowth was nearly threefold greater on glia derived from the cortex, retina, and olfactory bulb than on glia derived from mesencephalon, striatum, or spinal cord. This effect was principally on the number of primary dendrites rather than the elongation of individual dendrites. Similar morphological differences were observed when cortical neurons were grown on polylysine in a noncontact coculture system with glia continuously conditioning the media. This selective promotion of dendrite growth was independent of neuron survival. These results indicate that there are regional differences in the ability of CNS glia to support dendritic growth and that this effect is due, in part, to release of a diffusable factor.

[Key words: astrocyte, axon, cortex, dendrite, development, glia]

A number of factors have been observed to be important in regulating the growth of processes from neurons in the CNS. The factors necessary for the generation of a neuron's form derive (1) from constraints intrinsic to the cell and (2) from molecules within the complex microenvironment of the cell. The most well-studied examples of extrinsic factors are those derived from glial cells. Descriptive studies and both in vivo and in vitro manipulations indicate that neuron-glia interactions influence the generation and elaboration of neurites and provide a preferred substrate for neurite extension (Noble et al., 1984; Fallon, 1985; Tomaselli et al., 1986, 1988; Neugebauer et al., 1988; Smith et al., 1990; Norris and Kalil, 1991; Baird et al., 1992).

In addition to their general support of neurite growth from both central and peripheral neurons, there is increasing evidence that glial cells can regulate axonal and dendritic growth differ-

Received March 24, 1993; revised Dec. 9, 1993; accepted Dec. 21, 1993

This work was supported in part by NIH Grant NS30305 and a Brain Trauma Foundation award to P.D.L.R. We thank Ivar Klajvin, Raymond Anchan, Marcie Walker, Catrin Pittack, Chris Jasoni, Matt Kelley, Paul Schwarz, and H. Richard Winn for support and advice throughout this study and for useful comments on the manuscript.

Correspondence should be addressed to Peter D. Le Roux, Department of Neurosurgery RI 20, University of Washington, Seattle, WA 98195.

Copyright (C) 1994 Society for Neuroscience 0270-6474/94/144639-17\$05.00/0 ently. A variety of coculture experiments (summarized in Table 1) have been performed by several different laboratories, and the results have for the most part been consistent with the hypotheses that homotypic astroglial cells support a greater number of more highly branched dendrites, whereas target-derived astrocytes promote axonal growth (Prochiantz et al., 1990; Rousselet et al., 1990; Qian et al., 1992). For example, Prochiantz and colleagues (Denis-Donini et al., 1984; Chamak et al., 1987; Autillo-Touati et al., 1988; Rousselet et al., 1988, 1990; Prochiantz et al., 1990) have found that in the embryonic rodent CNS, both mesencephalic and striatal neurons elaborate a greater number of primary neurites when cocultured with astrocytes derived from the homotypic brain region. In addition to the effects on dendrite morphology, Rousselet et al. (1990) observed that mesencephalic neurons extended longer axons in media conditioned by striatal (target)-derived astrocytes than by mesencephalon-derived astrocytes. More recently, Qian et al. (1992) has extended these observations by demonstrating that axonal growth from either hippocampal or spinal neurons was specifically enhanced by target-derived astrocytes.

Several coculture experiments, however, have provided results that are in part inconsistent with this simple model. Whereas homotypic glial cells can induce dendritic growth from rat sympathetic neurons comparable to that observed in situ (Tropea et al., 1988), heterotypic cerebral cortical astrocytes can also support extensive neurite growth from these cells (Johnson et al., 1989). Furthermore, Denis-Donini and Estenoz (1988) reported that dopaminergic neurons of the substantia nigra exhibited more extensive neurite outgrowth on glia derived from the olfactory bulb than on homotypic or target-derived glia. Also, whereas Qian et al. (1992) found that axonal growth was differentially regulated by astrocytes derived from different brain regions, they failed to find any effects on dendrite number, similar to that described by Rousselet et al. (1990) for mesencephalic neurons.

Thus, it is unclear whether local or target glia are always better than homotypic glia at promoting appropriate neuronal morphology, or alternatively, the relevant difference between glial cells cultured from different areas might instead be their relative ability to support axonal or dendritic growth. Furthermore, it is not known whether glia from different $\mathrm{CNS}$ regions specifically influence cortical neurons in a selective neuroanatomic manner. We therefore decided to test this hypothesis by examining neuronal process outgrowth from cortical neurons in the presence of glia from a wide variety of CNS sources. Both axonal and dendritic growth from mouse cortical neurons in culture was quantified using double-labeled immunohistochemical techniques. Neurons were plated at low density and isolated neurons that were not in contact with other neurons were analyzed, since 
Table 1. Summary of published data analyzing the influence of glia from different regions of the central nervous system on neurite outgrowth

\begin{tabular}{|c|c|c|c|c|c|c|c|}
\hline Authors & Analysis & Glia & Neuron & Neurite \#/L & Axon & Dendrite \# & Dendrite L \\
\hline Le Roux and & $5 \mathrm{DIV}$ & Rat P4 & Mouse E18 & & & & \\
\hline \multirow[t]{7}{*}{ Reh, 1993} & M6 & SC & Ctx & & $172.7 \pm 6.7 \mu \mathrm{m}$ & $1.6 \pm 0.2$ & $16.7 \pm 1.8 \mu \mathrm{m}$ \\
\hline & MAP2 & Mes & & & $181.4 \pm 6.5 \mu \mathrm{m}$ & $1.4 \pm 0.1$ & $16.1 \pm 1.8 \mu \mathrm{m}$ \\
\hline & NF-200 & Str & & & $170.9 \pm 8.0 \mu \mathrm{m}$ & $1.4 \pm 0.1$ & $12.0 \pm 1.4 \mu \mathrm{m}$ \\
\hline & & $\mathrm{OB}$ & & & $179.2 \pm 8.9 \mu \mathrm{m}$ & $2.7 \pm 0.3$ & $19.3 \pm 1.6 \mu \mathrm{m}$ \\
\hline & & Ret & & & $161.9 \pm 4.3 \mu \mathrm{m}$ & $3.5 \pm 0.2$ & $19.5 \pm 1.3 \mu \mathrm{m}$ \\
\hline & & $\mathrm{Ctx}$ & & & $184.7 \pm 7.4 \mu \mathrm{m}$ & $4.3 \pm 0.3$ & $16.6 \pm 1.1 \mu \mathrm{m}$ \\
\hline & & $\begin{array}{l}\text { Contact } \\
\text { conta }\end{array}$ & & & & & \\
\hline
\end{tabular}

$\begin{array}{clll}\begin{array}{c}\text { Baird et al., } \\ 1992\end{array} & \begin{array}{l}\text { 2 DIV } \\ \text { M6 } \\ (\text { MAP2 })\end{array} & \begin{array}{l}\text { Mouse P3-P6 } \\ \text { Cereb }\end{array} & \begin{array}{l}\text { Mouse P0 } \\ \text { Pons explant }\end{array} \\ & \text { Non contact } & \\ & & & \\ \text { Qian et al., } & \text { 4 DIV } & \text { Rat P1-P3 } & \text { Rat E14-E18 } \\ 1992 & \text { MAP2 } & \text { SC } & \text { SC } \\ & \text { NF-200 } & \text { Cereb (target) } & \text { SC } \\ & & \text { Ctx } & \text { SC } \\ & & & \\ & & \text { Hip } & \text { Hip } \\ & & \text { Ctx (target) } & \text { Hip }\end{array}$
Ctx (target) Hip

\begin{tabular}{|c|c|c|c|c|}
\hline \multirow[t]{2}{*}{$\begin{array}{l}\text { Rousselet et } \\
\text { al., } 1990\end{array}$} & \multirow[t]{2}{*}{$\begin{array}{l}2 \text { DIV } \\
\text { Toluidine blue } \\
\text { (NF-200) } \\
\text { (MAP2) }\end{array}$} & $\begin{array}{l}\text { Rat El4 } \\
\text { Mes CM }\end{array}$ & $\begin{array}{l}\text { Rat E14 } \\
\text { Mes }\end{array}$ & $\begin{array}{l}3.5 \text { neurites' per neuron, to- } \\
\text { tal length } 255.8 \pm 5.3 \mu \\
\text { longest } 116.8 \pm 3.7 \mu^{\mu}\end{array}$ \\
\hline & & Str $\mathrm{CM}$ & Mes & $\begin{array}{l}2 \text { neurites }{ }^{h} \text { per neuron, total } \\
\text { length } 209.8 \pm 8.0 \mu \text {, lon- } \\
\text { gest } 173.2 \pm 5.7 \mu\end{array}$ \\
\hline $\begin{array}{c}\text { Rousselet et } \\
\text { al., } 1988\end{array}$ & $\begin{array}{l}2 \text { DIV } \\
\text { Toluidine blue }\end{array}$ & $\begin{array}{l}\text { Rat E14-E16 } \\
\text { Mes CM }\end{array}$ & $\begin{array}{l}\text { Rat E14-E16 } \\
\text { Mes }\end{array}$ & $\begin{array}{l}57 \% \cdot \text { neurons } \\
\geq 4 \text { neurites }\end{array}$ \\
\hline & NF & Str $\mathrm{CM}$ & Mes & $\begin{array}{l}30 \% \text { neurons } \\
\cong 4 \text { ncuritcs } \\
\text { Total neurite length } \\
\text { Mes } \mathrm{CM}>\text { Str CM, } \\
\text { differed by }<20 \%\end{array}$ \\
\hline $\begin{array}{l}\text { Dennis-Don- } \\
\text { nini and } \\
\text { Estenoz, } \\
1988\end{array}$ & $\begin{array}{l}3 \text { DIV } \\
3 \text { H DA-AR }\end{array}$ & $\begin{array}{l}\text { Mouse } \\
\text { OB } \\
\text { Mes } \\
\text { Str }\end{array}$ & $\begin{array}{l}\text { Mouse E13 } \\
\text { Mes } \\
\text { Mes } \\
\text { Mes }\end{array}$ & $\begin{array}{l}\text { Total neuritic output" } \\
\begin{array}{l}2450 \pm 900 \mu \mathrm{m} \\
1347 \pm 320 \mu \mathrm{m} \\
725 \pm 210 \mu \mathrm{m}\end{array}\end{array}$ \\
\hline $\begin{array}{l}\text { Autillo et al., } \\
\quad 1988\end{array}$ & $\begin{array}{l}2 \text { DIV } \\
\text { NF } \\
\mathrm{em}\end{array}$ & $\begin{array}{l}\text { Mouse E15 } \\
\text { Mes }\end{array}$ & $\begin{array}{l}\text { Mouse E15 } \\
\text { Mes }\end{array}$ & $\begin{array}{l}47 \% \text { neurons } \\
\geq 3 \text { neurites }\end{array}$ \\
\hline & & Str & Mes & $\begin{array}{l}15 \% \text { neurons } \\
\geq 3 \text { neurites }\end{array}$ \\
\hline $\begin{array}{r}\text { Chamak et } \\
\text { al., } 1987\end{array}$ & $\begin{array}{l}2 \text { DIV } \\
\text { MAP2 }\end{array}$ & $\begin{array}{l}\text { Rat E15 } \\
\text { Mes }\end{array}$ & $\begin{array}{l}\text { Rat E15 } \\
\text { Mes }\end{array}$ & \\
\hline
\end{tabular}

Increased "axon"

length observed on glia. No effect observed with conditioned media. Tar. get neurons stopped neurite growth.
$132.6 \pm 7.7 \mu \mathrm{m}^{\prime \prime}$ $575.9 \pm 40.6 \mu \mathrm{m}$ $112.2 \pm 6.5 \mu \mathrm{m}$

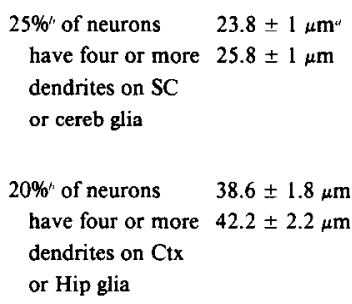
Primary dendrite

number, and, to a lesser extent, length, but not axonal growth, are influenced by glia in a region-selective manner. In part, this is mediated by a diffusible factor.

In absence of target neurons, glia provide + signal to axons. Cell-cell contact required.

Target derived glia increase axon length. Cell-cell contact is not necessary.

Dendritic outgrowth is not influenced by glia in a neuroanatomic-specific manner.

Increased number of primary neurites initiated in homotypic glial media.

“Dendritic" like neurites preferentially initiated in homotypic glial media.

Longest neurite on non homotypic, nontarget glia.

Cell-cell contact required. No neuroanatomic-selective glial influence on OB neurons observed.

Increased primary neurites and branches on homotypic glia. Length not analyzed.

$40 \% "$

$\geq 3$ MAP2-IR

neurites

(mean \pm 2 )

$20 \%{ }^{\prime}$ neurons

$\geq 3$ MAP2-IR

neurites

(mean \pm 1.5$)$
Increased primary

neurites and

branches on homotypic glia Length not analyzed. A similar but lcss pronounced effect was observed for Str neurons cultured on Mes or Str glia. 
Table 1. Continued

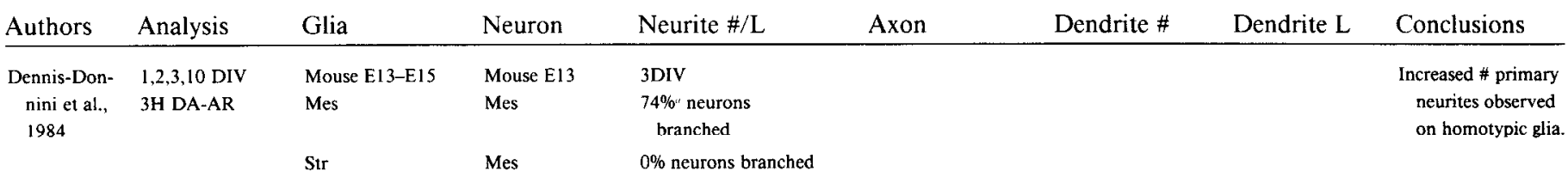

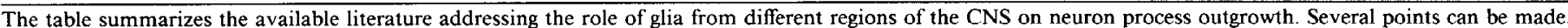

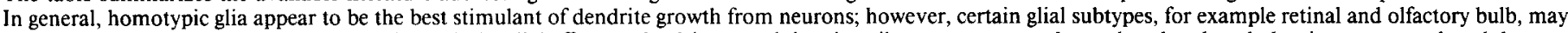

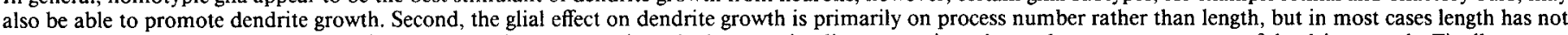

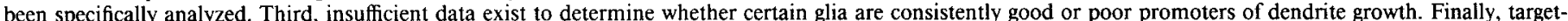

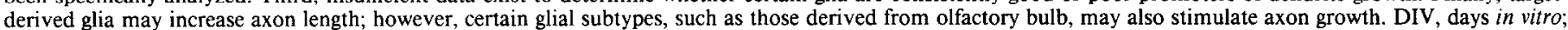

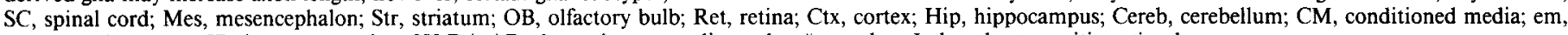
electron microscopy; IR, immunoreactive; $3 \mathrm{H}$ DA-AR, dopamine autoradiography; \#, number; L, length; +, positive stimulus.

"Data reported in the paper.

An estimate derived from tables or figures reported in the paper.

there is evidence that increased neuron density (Chamak et al., 1987; Bruckenstein and Higgins, 1988; Mattson et al., 1989), synaptic activity (Rubel et al., 1981; Deitch and Rubel, 1984; Schilling et al., 1991), the presence of axons, and the local application of neurotransmitters (Mattson et al., 1988, 1989) can all influence neurite growth. The data reported here demonstrate that while glia are generally permissive for neurite growth, glia from different regions of the CNS differ in their ability to support dendritic, but not axonal, growth from mouse cortical neurons in vitro. The ability to support extensive dendritic growth from cortical neurons, however, is not confined to either homotypic or target-derived glia and, in part, is due to the release of a diffusable factor.

\section{Materials and Methods}

Dissociated cerebral cortex neuronal cultures. Pregnant Balb/c mice (E18) were killed by decapitation following $\mathrm{CO}_{2}$ anesthesia and the embryos removed under sterile conditions. Frontal cerebral cortex was dissected in sterile Hank's balanced salt solution (HBSS). The cortex was minced into $1 \mathrm{~mm}$ pieces and dissociated into a single-cell suspension using the following protocol: (1) Pieces of frontal cortex were placed in $5 \mathrm{ml}$ of $\mathrm{Ca}^{2+} / \mathrm{Mg}^{2+}$-free HBSS. (2) The pieces of cortex were incubated at room temperature in this solution for $10 \mathrm{~min}$ and then $0.5 \mathrm{ml}$ of a $2.5 \%$ trypsin solution was added. (3) The incubation was continued for another $10 \mathrm{~min}$ on a shaking device at $37^{\circ} \mathrm{C}$. At the end of incubation, the trypsin was inactivated by adding $0.5 \mathrm{ml}$ of fetal bovine serum. (4) The cells were then concentrated by centrifugation $(1500 \mathrm{rpm}, 5 \mathrm{~min})$ and the supernatant was removed. (5) Fresh medium $(2 \mathrm{ml})$ was added and the pellet was triturated to a single-cell suspension. (6) The cells were plated in DMEM : F12 (without glutamate or aspartate; GIBCO, Grand Island, NY) supplemented with insulin $(25 \mu \mathrm{g} / \mathrm{ml})$, transferrin $(100 \mu \mathrm{g} / \mathrm{ml})$, putrescine $(60 \mu \mathrm{M})$, selenium $(30 \mathrm{nM})$, progesterone (20 $\mathrm{nM})$, and penicillin/streptomycin. For all experiments, the cortical neurons were plated at low density $\left(1 \times 10^{4}\right.$ cells $\left./ \mathrm{ml}\right)$ and maintained for $5 \mathrm{~d}$ either on astroglial substrates (see below) in serum-free media (above), or poly-D-lysine $(50-100 \mu \mathrm{g} / \mathrm{ml})$-coated coverslips in the presence of continuously conditioned astroglial media (see below). Cells were grown at $37^{\circ} \mathrm{C}$ in an atmosphere of $5 \% \mathrm{CO}_{2}$.

Glial cell cultures. Astroglial cultures from different CNS regions were obtaincd from postnatal day 4 rat pups. After careful removal of the meninges, pieces of frontal cerebral cortex, mesencephalon, olfactory bulb, striatum, spinal cord, or the entire retina were dissociated on a shaking device in $\mathrm{Ca}^{2+} / \mathrm{Mg}^{2+}$-free HBSS containing $0.25 \%$ trypsin at $37^{\circ} \mathrm{C}$ for $20 \mathrm{~min}$. At the end of the incubation the trypsin was inactivated with $0.5 \mathrm{ml}$ of fetal bovine serum. The cells were collected by centrifugation (1500 rpm, $5 \mathrm{~min}$ ) and the supernatant removed. Fresh medium $(2 \mathrm{ml})$ was added and the cells triturated to a single-cell suspension. The cells were then plated (approximately $1 \times 10^{5}$ cells $/ \mathrm{ml}$ ) in $25 \mathrm{ml}$ plastic tissue culture flasks and maintained in $10 \%$ serum-containing media (DMEM and Hams F-12, GIBCO) until they reached confluence (10$14 \mathrm{~d})$. Glial cultures were purified for astrocytes or Müller glia using a modification of published methods (Levison and McCarthy, 1991).
Briefly, confluent monolayers were shaken overnight $(250 \mathrm{rpm}$ for 18 hr at $37^{\circ} \mathrm{C}$ ) to remove loosely adherent phase-bright cells. The remaining attached cells were first washed in HBSS and then exposed to $0.25 \%$ trypsin in $\mathrm{Ca}^{2+} / \mathrm{Mg}^{2+}$-free HBSS for $30 \mathrm{sec}$. The cells were then incubated in $\mathrm{Ca}^{2}+\mathrm{Mg}^{2}-$ free HBSS at $37^{\circ} \mathrm{C}$ for $5 \mathrm{~min}$ and further detached cells discarded. The remaining adherent cells were removed from the flasks following incubation in $\mathrm{Ca}^{2+} / \mathrm{Mg}^{2+}$-free HBSS containing $0.1 \%$ trypsin at $37^{\circ} \mathrm{C}$ for $5 \mathrm{~min}$. After this incubation, the trypsin was inactivated with fetal bovine serum and the remaining cells were rinsed in serum-containing media and dispersed. The cells were then plated (approximately $1 \times 10^{5} \mathrm{cells} / \mathrm{ml}$ ) onto glass coverslips, coated with either poly-D-lysine/laminin $(20 \mu \mathrm{g} / \mathrm{ml})$ for Müller glia or poly-D-lysine for other glial subpopulations, placed in individual wells of a 24 -well plate, and allowed to form a confluent monolayer (2-5 d). Once a confluent monolayer was formed, mouse cortical neurons were introduced. Approximately $90 \%$ of the non-neuronal cells in these cultures were immunoreactive for GFAP or vimentin (see Results) and appeared as large flat cells. Fibroblast monolayers were derived from the meninges of $\mathrm{P} 4$ rat pup meninges and prepared as described above. For all the coculture experiments, the cells were maintained in chemically defined media as described above for dissociated neuronal cultures.

Noncontact transfilter experiments. To test for the effect of secreted factors from astroglia, purified glial cells were obtained as described for glial cultures above. Cells were then plated at high density (approximately $1 \times 10^{5}$ cells $\left./ \mathrm{ml}\right)$ on Millicell culture inserts $(0.4 \mu \mathrm{m})$ in 24-well plates and allowed to grow to confluence. For noncontact coculture experiments, cortical neurons were plated at low density $\left(1 \times 10^{4}\right.$ cells $\mathrm{ml})$ onto poly-D-lysine $(50-100 \mu \mathrm{g} / \mathrm{ml})$-coated coverslips located beneath the millipore filter. Small legs elevate the filter over each coverslip; thus, neurons are continuously exposed to astroglial-conditioned media. Cells were grown at $37^{\circ} \mathrm{C}$ in an atmosphere of $5 \% \mathrm{CO}_{2}$.

Immunohistochemical identification of cells in culture. Different glial cell types were distinguished using the following monoclonal or polyclonal antibodies: anti-GFAP (glial fibrillary acidic protein; BoehringerMannheim, Indianapolis, IN; 1:100), anti-vimentin (Boehringer-Mannheim; 1:100), $\mathrm{A}_{2} \mathrm{~B}_{5}$ (hybridoma supernatant; American Tissue Type Collection, Rockville, MD; 1:10), Thy 1.1 (OX7 clone ascites; Cedar Lane, Hornby, Ontario), nerve growth factor receptor (NGFR)-specific rat monoclonal antibody (RAT $192 \mathrm{Ig}$; generously donated by Dr. Mark Bothwell, University of Washington, Seattle; WA), Nestin (RAT 401, generously provided by Dr. Susan Hockfield, Yale University, New Haven, CT), galactocerebroside antiserum (Gal-C; Chemicon, Temecula, CA; 1:50), and a polyclonal antiserum raised in rabbits against cellular retinaldehyde-binding protein (CRALBP; from Dr. J. Sarri, University of Washington, Seattle). Supernatant from hybridoma cells was used without dilution, while ascites from these cells was typically diluted 1:10. A minimum of five coverslips were labeled with each antibody and labeled cells were counted from a minimum of five arbitrarily selected fields to determine the cellular phenotypic composition of the glial monolayers. Monoclonal antibodies against rhodopsin, Rho-4D2, and Rho 2A4 were obtained from a hybridoma cell line (generous gift of Drs. R. Molday and D. Hicks, University of British Columbia, Vancouver) and were used to identify photoreceptors in retinal cultures. Mouse neurites were immunostained with a mouse neuron-specific monoclonal antibody, M6 (hybridoma cell line generously donated by Dr. C. Lagenaur, University of Pittsburgh, Pittsburgh, PA; 1:10). Axons 
were identified with a rabbit polyclonal antiserum to the $200 \mathrm{kDa}$ neurofilament protein (NF-H; Sigma, St. Louis, MO; 1:200). A monoclonal antibody to microtubule-associated protein 2, (MAP2; BoehringerMannheim; $1: 100$ ) was used as a specific marker of dendrites.

Prior to immunostaining, coverslips were fixed in $4 \%$ paraformaldehyde $\left(0.1 \mathrm{~m}\right.$ phosphate buffer, $4 \%$ sucrose, $\left.\mathrm{pH} 7.4,60 \mathrm{~min}, 20^{\circ} \mathrm{C}\right)$ and then washed three times in $0.1 \mathrm{M}$ phosphate buffer (PBS). In order to visualize cell surface antigens such as those recognized by $A_{2} B_{5}$, Thy 1.1, M6, or Gal-C, cells were first incubated in $0.1 \mathrm{M}$ PBS containing $1 \%$ bovine serum albumin (Sigma; $30 \mathrm{~min}, 20^{\circ} \mathrm{C}$ ); to visualize intracellular antigens such as NF-H or MAP2, cells were permeabilized with $0.05 \%$ Triton X-100 (0.1 M PBS, $1 \%$ bovine serum albumin, $30 \mathrm{~min}$, $20^{\circ} \mathrm{C}$. Primary antibodies were diluted in PBS with or without $0.3 \%$ Triton $\mathrm{X}$ and incubated for $1 \mathrm{hr}$ at $20^{\circ} \mathrm{C}$. After the primary incubation, the cells were washed three times in PBS containing 4\% goat serum (Sigma). Labeling was detected with fluorescein- or rhodamine-conjugated antibodies $\left(1: 200\right.$ in PBS, $\left.1 \mathrm{hr}, 20^{\circ} \mathrm{C}\right)$. Mouse antibodies were visualized with fluorescein-coupled goat anti-mouse Ig (Cappel, Organon Technika, Durham, NC). Rabbit or rat antibodies were visualized using direct or indirect immunofluorescence with rhodamine-conjugated goat anti-rat or anti-rabbit Ig. In some cases, indirect immunofluorescent labeling was carried out using biotinylated secondary antibodies (anti-mouse or anti-rabbit IgG from Sigma Chemicals; $10 \mu \mathrm{g} / \mathrm{ml}$ ) followed by avidin-TRITC (Sigma) or streptavidin-FITC (Molecular Probes, Eugene, OR). Omission of the primary antibody eliminated the observed immunoreactivity on the various cultures. Immunostained cultures were washed in PBS and mounted onto glass slides in aqueous mounting solution (Fluoromount).

Analysis of cortical neuron survival and process outgrowth. Neuronal survival was assessed by measuring plating efficiency of purified neurons at 1,3 , and $5 \mathrm{~d}$ in vitro using both morphologic and immunocytochemical techniques. At each time point the number of neurons was counted microscopically and expressed as a percentage of the number of cells plated. The growth of neurites from cortical neurons identified by MAP2 immunoreactivity was analyzed after $5 \mathrm{~d}$ in vitro. Immunoreactive cells were examined in six different microscopic fields selected at random on a minimum of five coverslips for each experimental condition. At least three experiments for each test substrate/cell monolayer were carried out. Analysis of statistical significance of any observed differences between substrates was done using a $t$ test or ANOVA. For measurements of neurite length, neurons were examined at a final image magnification of $400 \times$. Only isolated neurons whose cell bodies or processes were not in contact with other neurons were analyzed. Fluorescent images of the neurons were recorded with an image intensifier coupled to a $C C D$ video camera (Motion Analysis, Eugene, OR) and analyzed with a Macintosh II image processing program (IMAGE ANALYST; Automax, Billerica, MA). Neurite lengths were measured by tracing the total length of any neurite extending from a neuron cell body. Recorded lengths were calibrated at the same magnification using a microscope slide micrometer.

\section{Results}

Dendrite identification

In order to characterize the identity of a neuritic process as either a dendrite or axon, morphological and immunohistochemical criteria were used. Neurites were classified as dendrites if they demonstrated immunoreactivity for microtubule-associated protein 2 (MAP2; Cáceres et al., 1984, 1986; Matus et al., 1986; Pennypacker et al., 1991) and were tapered, with their length being proportional to the diameter of the stem. By contrast, axons were immunoreactive for the $200 \mathrm{kDa}$ neurofilament protein, NF-H (Pennypacker et al., 1991), and were more uniform in diameter, longer, less branched and followed a wandering course.

Previous studies that have examined the time course of process outgrowth from hippocampal (Cáccres et al., 1986; Dotti et al., 1988; Pennypacker et al., 1991) or rat cortical neurons (Kosik and Finch, 1987) in vitro indicate that neither morphologic features nor segregation of cytoskeletal elements is coincident with the elaboration of processes but instead both are achieved after 3 DIV. Therefore, to determine the earliest time point at which axons and dendrites from mouse cortical neurons could be distinguished, we examined the morphology and segregation of cytoskeletal elements in (E18) mouse cortical neurons at $1,2,3$, and $5 \mathrm{~d}$ in vitro. Within $1 \mathrm{~d}$ of plating most neurons had begun to extend processes. Typically, there was a single long process and several shorter ones. Apart from length, there were no morphological features that differentiated axons from dendrites and all processes were immunoreactive for MAP2. NF-H immunoreactivity was not expressed in any process. At 2 DIV, NF-H expression was identified in occasional neurites but always colocalized with MAP2 immunoreactivity, including in presumptive dendrites. After $3 \mathrm{DIV}$, neurites were longer and morphological features of axons or dendrites were present in most cells examined. Again, MAP2 was identified in virtually all processes and often coexisted with NF-H in the longest process. A few presumptive axons expressed only MAP2, and trequently MAP2 could be traced to the distal tip of the axon. At $5 \mathrm{~d}$ in vitro, neurites had distinct axonal or dendritic morphology, and the localization of MAP2 and NF-H to the dendritic or axonal compartment, respectively, was clear. In order to label entire cells and their processes, we used an additional antibody, M6. This antibody recognizes an antigen that is present on the surface of mouse neurons and their processes (Lund et al., 1985). Throughout the period examined (1-5 d in vitro), M6 immunoreactivity was present in all of the processes. Therefore, at 5 $\mathrm{d}$ in vitro, a cortical neuronal process was classified as a dendrite if it was immunoreactive for both M6 and MAP2 and/or lacked immunoreactivity for NF-H. Alternatively, at $5 \mathrm{~d}$ in vitro a cortical neuronal process was classified as an axon if it was M6 and NF-H immunoreactive and/or lacked MAP2 immunoreactivity (Fig. 1).

\section{Glial characterization}

There is increasing evidence that astrocytes are not a homogeneous population (for review, see Hansson, 1988; Barres, 1991). Several lines of evidence suggest that glia from different regions of the CNS differ in their ability to promote neurite outgrowth (Denis-Donini et al., 1984; Chamak et al., 1987; Autillo-Touati et al., 1988; Denis-Donini and Estenoz, 1988; Prochiantz et al., 1990; Qian et al., 1992). Table 1 summarizes these results. Two points are apparent. First, there have been relatively few studies that have quantitatively examined the effects of glia from different CNS regions on both axon and dendrite growth. Second, there is insufficient information to conclude whether certain glia are, in general, better promoters of dendrite growth than other glia. Taken together, these studies suggest that homotypic glia are more effective at promoting dendritic growth whereas targetderived glia are more effective promoting axonal growth. The results of some experiments, however, suggest that glia derived from particular CNS regions, for example olfactory bulb, are generally more effective promotors of neurite growth. Therefore, in the present study, glial cells were derived from a wide variety of different CNS regions including cortex, striatum, mesencephalon, spinal cord, olfactory bulb, and retina from early postnatal (P4) rats. Glia, when cultured in this manner, contained few if any neurons. MAP2 and NF-H immunoreactivity was not detected in the glial monolayers. To characterize the cellular composition of the monolayers, cultures were stained with a nuclear stain, 4',6-diamido-2-phenyl indole (DAPI; Sigma) and cell type-specific antibodies. The number of immunoreactive cells was then calculated as a percentage of the total number of cells present. Immunohistochemical characterization demon- 

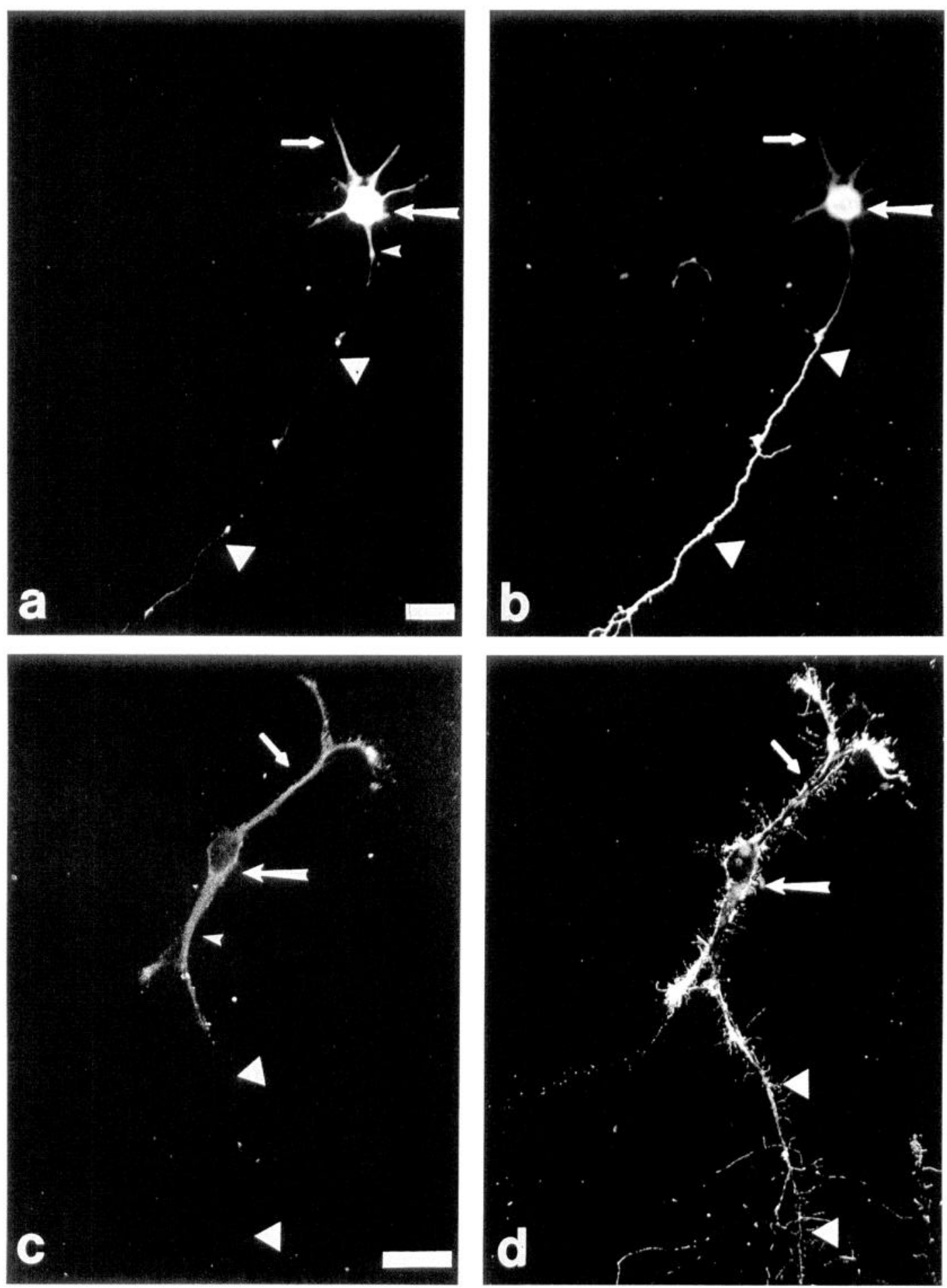

Figure 1. Distribution of MAP2, NF-H, and M6 in cortical neurons: corresponding fluorescent photomicrographs of E18 mouse cortical neurons grown for $5 \mathrm{~d}$ in vitro and labeled with MAP2 ( $a$ and $c), \mathrm{NF}-\mathrm{H}(b)$, and M6 $(d)$. MAP2 staining is present in the cell body (large arrow), straight, short, tapering neurites typical of dendrites (small arrow), and the proximal portion of the axon (small arrowhead). The remaining axon does not contain detectable MAP2 (large arrowhead). There is a paucity of NF-H label $(b)$ in the soma (large arrow) and dendrites (small arrow), but intensive staining in the axon (large arrowheads). M6 labeling $(d)$ is distributed on the cell surface of the soma (large arrow) and all processes and is only found in mouse neurons. Scale bars, $10 \mu \mathrm{m}$.

strated that the majority of the cells $(83.5-89.5 \%)$ could be classified as type I astrocytes based on morphology and GFAP immunoreactivity (Table 2). Most cells exhibited a flat, polygonal morphology (Fig. 2). Some isolated astroglial cells were multipolar and occasional, labeled cells were stellate in mor- phology. In most of the monolayers, few cells had the immunohistochemical phenotype of type II astrocytes (GFAP+, $\mathrm{A}_{2} \mathrm{~B}_{5}+$ ); however, in the cortical cultures, $13.7 \%$ of the cells could be classified as type II astrocytes on the basis of these antigens. Staining with galactocerebroside and Thy $1.1 \mathrm{dem}-$ 
Table 2. Cellular composition of astroglial monolayers

\begin{tabular}{|c|c|c|c|c|c|c|c|c|}
\hline Cell type & $\begin{array}{l}\text { Antigenic } \\
\text { marker }\end{array}$ & FIB & $\mathrm{SC}$ & MES & STR & $\mathrm{OB}$ & RET & CTX \\
\hline Type I astrocyte & $\mathrm{GFAP}+/ \mathrm{A}_{2} \mathrm{~B}_{5}-$ & - & 83.5 & 83.5 & 86.4 & 33.7 & - & 89.5 \\
\hline Type II astrocyte & $\mathrm{GFAP}+/ \mathrm{A}_{2} \mathrm{~B}_{3}+$ & - & 0.5 & 2 & 1 & - & - & 13.7 \\
\hline $\mathrm{O} 2 \mathrm{~A}$ progenitor & GFAP $-/ \mathbf{A}_{2} \mathbf{B}_{5}+$ & - & - & - & - & - & - & - \\
\hline Oligodendrocyte & $\mathrm{GFAP}-/ \mathrm{Gal}-\mathrm{C}+$ & - & 1.5 & 1.5 & 1 & - & - & 2.3 \\
\hline Fibroblast & Thy $1.1+$ & 92.6 & - & 4.2 & - & 1.7 & 0.25 & 2.2 \\
\hline Neuron & $\mathrm{MAP} 2+/ \mathrm{NF}+$ & - & - & - & - & - & - & - \\
\hline Müller glia & $\mathrm{VM}+/ \mathrm{CRABLP}+$ & - & - & - & - & - & 86.5 & - \\
\hline Ensheathing glia & $\mathrm{GFAP}+/ \mathrm{NGFR}+$ & - & - & - & - & 14 & - & - \\
\hline Immature glia & $\mathrm{VM}+$ & - & 18 & 53 & 82 & 88 & - & 83.5 \\
\hline Progenitor & Rat $401+$ & - & - & - & - & - & - & - \\
\hline Mouse contaminant & $\mathrm{M} 2+/ \mathrm{M} 6+$ & - & - & - & - & - & - & - \\
\hline
\end{tabular}

Astroglial cells were derived from early postnatal (P4) rat CNS regions as described in Materials and Methods and characterized with cell-specific antibodies. Data are expressed as the percentage of total cells identified by a nuclear stain (DAPI) that are immunoreactive for a specific antibody ( - indicates not detected). Five random fields from five coverslips of each monolayer were examined from three independent cultures. The total number of cells counted for each CNS region ranged from 750 to 1000 . Immunohistochemical characterization indicates (1) the complete absence of neurons and (2) the majority of cells are either GFAP or vimentin positive and therefore represent astroglia at various maturational stages. FIB, fibroblasts from meninges; SC, spinal cord; MES, mesencephalon; STR, striatum; OB, olfactory bulb; RET, retina; CTX, cortex.

onstrated few oligodendrocytes and fibroblasts, respectively, in any of the glial monolayers.

The immunohistochemical and morphological characteristics of the monolayers were very similar for astroglia derived from most CNS regions examined (Table 2). Whereas retinal and olfactory bulb glia were morphologically similar to glia from other regions, they demonstrated immunohistochemical differences. The majority of cells in the retinal glia cultures expressed vimentin and cellular retinaldehyde binding protein (CRALBP). The latter antibody is expressed specifically by Müller glia in the sensory retina (de Leeuw et al., 1990). In the olfactory bulb, the following distinct cell populations could be distinguished: (1) flat cells with a typical astrocyte morphology that were immunoreactive for vimentin, and (2) elongated cells with fairly long processes that extended across the surface of other cells. Although these latter cells resembled the O2A progenitors (see Raff, 1989, for review), immunoreactivity for $A_{2} B_{5}$ was not detected. By contrast, these cells expressed GFAP and the lowaffinity NGF receptor, as detected by the monoclonal antibody 192, and may represent olfactory ensheathing glia (Doucette, 1990; Vickland et al., 1991). The majority of cells in the cortex and striatum as well as many cells in the mesencephalon expressed both GFAP and vimentin. By contrast, very few spinal cord glia expressed both antigens, while most olfactory bulb and retinal glia displayed vimentin immunoreactivity only. No immunoreactivity was observed for Nestin (RAT 401) in any of the cell populations examined. Vimentin cross-reactivity was not observed with Thy 1.1 or neurons that expressed NF-H or MAP2.

\section{Dendritic growth is selectively influenced by the anatomic source of the astroglial monolayer}

We analyzed the potential influence of astroglia from different CNS regions on cortical neuron dendrite growth. In order to identify clearly the full extent of the processes from cortical neurons, embryonic (E18) mouse cortical neurons were cocultured onto rat astroglial monolayers and the antibody M6 was used to label selectively the mouse neurons (Lund et al., 1985). The M6 antigen was distributed on all processes of the neurons, with patches of continuous labeling alternating with punctate staining. As we were principally interested in the effect of glia on dendrite growth, we plated neurons at low density $\left(1 \times 10^{4}\right.$ cclls $/ \mathrm{ml}$ ) and only analyzed isolated neurons, that is, those not in contact with other neurons, that were double immunoreactive for M6 and MAP2 or NF-H. Neurite outgrowth was analyzed after $5 \mathrm{~d}$ in vitro to allow for the selective localization of MAP2 and NF-H to dendrites and axons, respectively.

Figure 3 illustrates the main differences observed in the morphologic aspects of cortical neurons grown for $5 \mathrm{~d}$ in vitro on different glial monolayers. On monolayers generated from cortex, retina, and olfactory bulb, most neurons were round, multipolar, and extended one long process and several shorter processes (Fig. 3b,d,f). By contrast, neurons grown on striatal, mesencephalic, or spinal cord glia exhibited a unipolar or bipolar morphology (Fig. 3a,c,e), but again with one process much longer than the other. The neuronal processes were characterized using antibodies directed against NF-H and MAP2 to identify axon and dendrites, respectively. The results of this analysis are illustrated in Figure 4 and Table 3. On cortical or retinal glial monolayers, the cortical neurons had an average of three or more primary dendrites. By contrast, almost all neurons (86.4$100 \%$ ) grown on striatal, mesencephalic, or spinal cord glia extended only one or occasionally two MAP2-immunoreactive processes (Table 3 ). Between $56.2 \%$ and $81.7 \%$ of primary dendrites were greater than $10 \mu \mathrm{m}$ in length. With the exception of striatal glia, the length of individual primary dendrites did not significantly differ on the different astroglial monolayers (Fig. 4). When neurons were grown on glia from the striatum, only $12 \%$ of primary dendrites achieved lengths greater than $20 \mu \mathrm{m}$. By contrast, $25.5-42.9 \%$ of primary dendrites examined on other monolayers had lengths greater than $20 \mu \mathrm{m}$. Dendrites tapered and grew directly from the cell body in a relatively straight direction. Branch points were seen from only a few primary dendrites, particularly those growing on cortical or retinal monolayers or when contact had been made with other neurons. Too few branch points were demonstrated to quantify this observation.

To characterize further the influence of astroglia on primary 

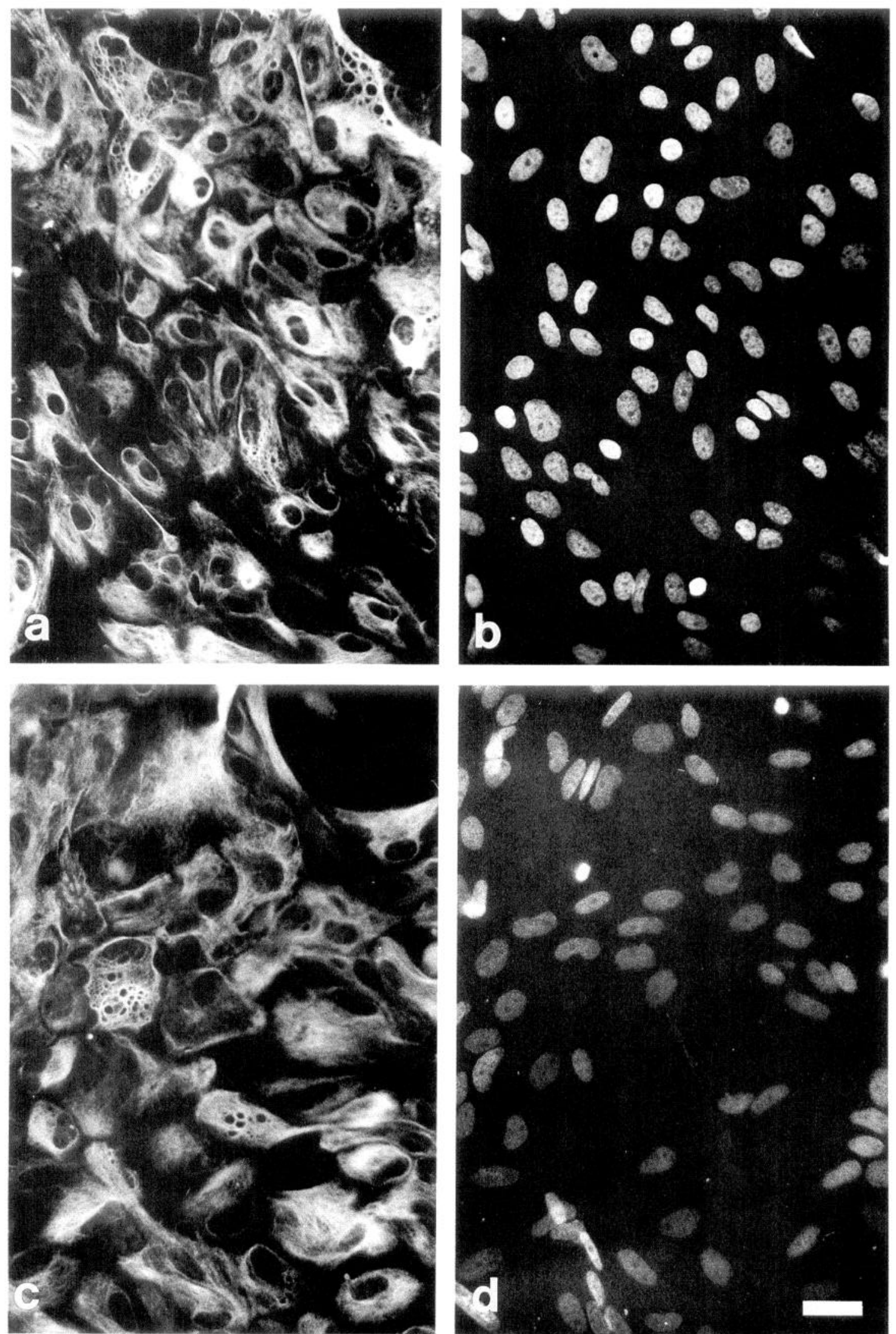

Figure 2. Astroglial monolayers were prepared from different CNS regions as described in Materials and Methods: representative fluorescent photomicrographs of astroglial monolayers derived from cortex $(a$ and $b)$ and mesencephalon $(c$ and $d)$, labeled with anti-GFAP $(a$ and $c)$ and DAPI $(b$ and $d$ ). The majority of cells demonstrated a flat polygonal morphology and could be classified as astrocytes. Scale bar, $10 \mu \mathrm{m}$. 

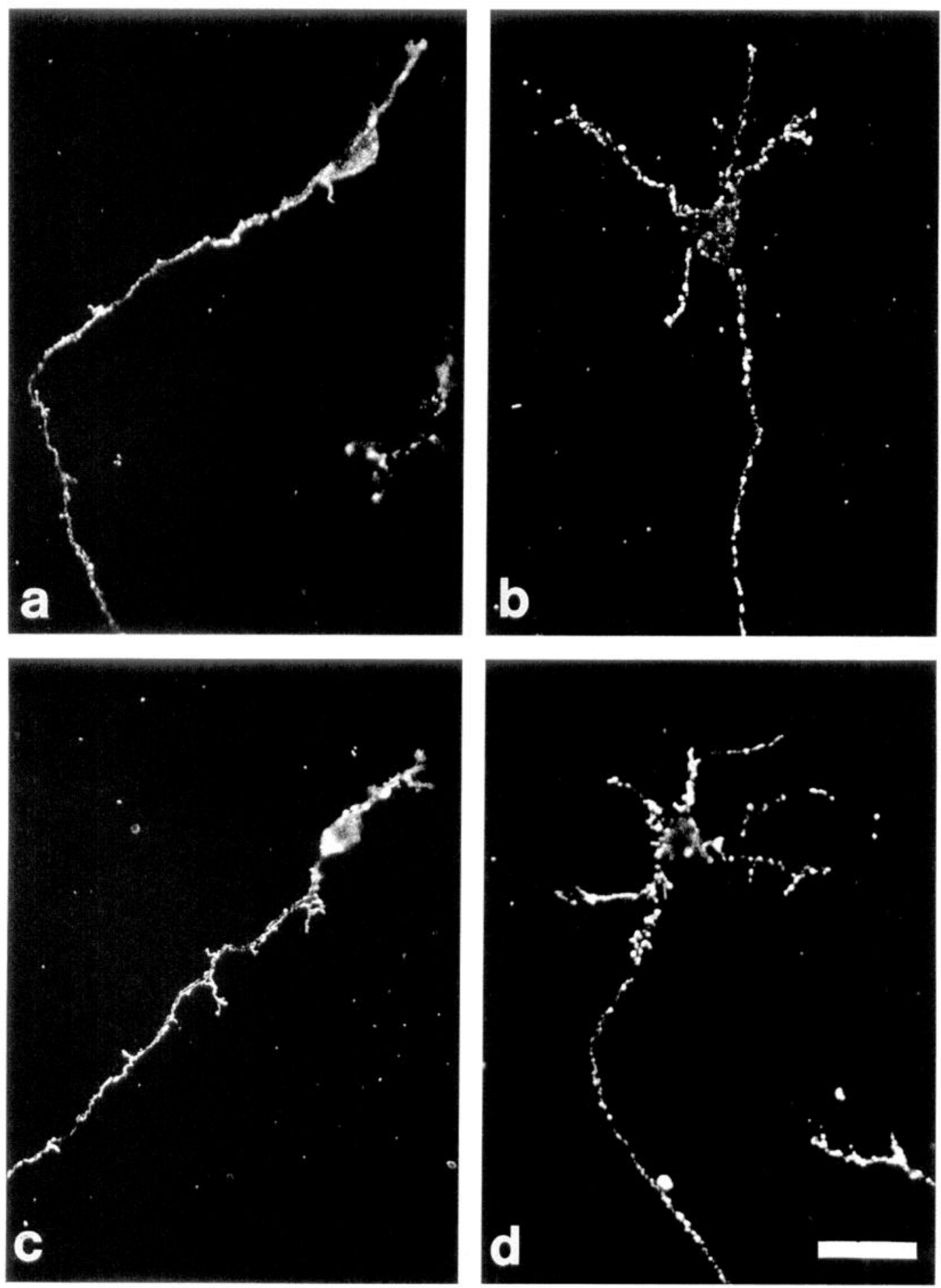

Figure 3. Cortical neurons growing on different glial monolayers in vitro exhibit striking dendritic differences dependent on the CNS region from which the glia are derived: representative fluorescent photomicrographs of E18 mouse cortical neurons labeled with anti-M6 after $5 \mathrm{~d}$ in vitro (a$d)$. Whereas axonal growth was similar on all monolayers tested, on glial monolayers derived from spinal cord, mesencephalon, or striatum ( $a$ and $c)$, neurons do not demonstrate an extensive dendritic arbor and usually exhibit a uni- or bipolar morphology. By contrast, on glial monolayers generated from the retina, olfactory bulb, or cortex $(b$ and $d)$, most neurons are multipolar and extend an axon and several dendrites. Neurons grown on polylysine-coated coverslips in continuously conditioned glial medium, exhibit similar morphologic differences, depending on the CNS source of the glia. $e$ and $f$, Lower-power micrographs of E18 mouse cortical neurons grown on astrocyte monolayers derived from mesencephalon $(e)$ and cerebral cortex $(f)$ show that although the axons are of similar length (arrowheads), the neuron growing on the cortical astrocytes has four dendrites extending from the cell soma, while the neuron growing on mesencephalon has only two dendrites (arrows). Scale bars, $10 \mu \mathrm{m}(a-d, e$ and $f$ ). 

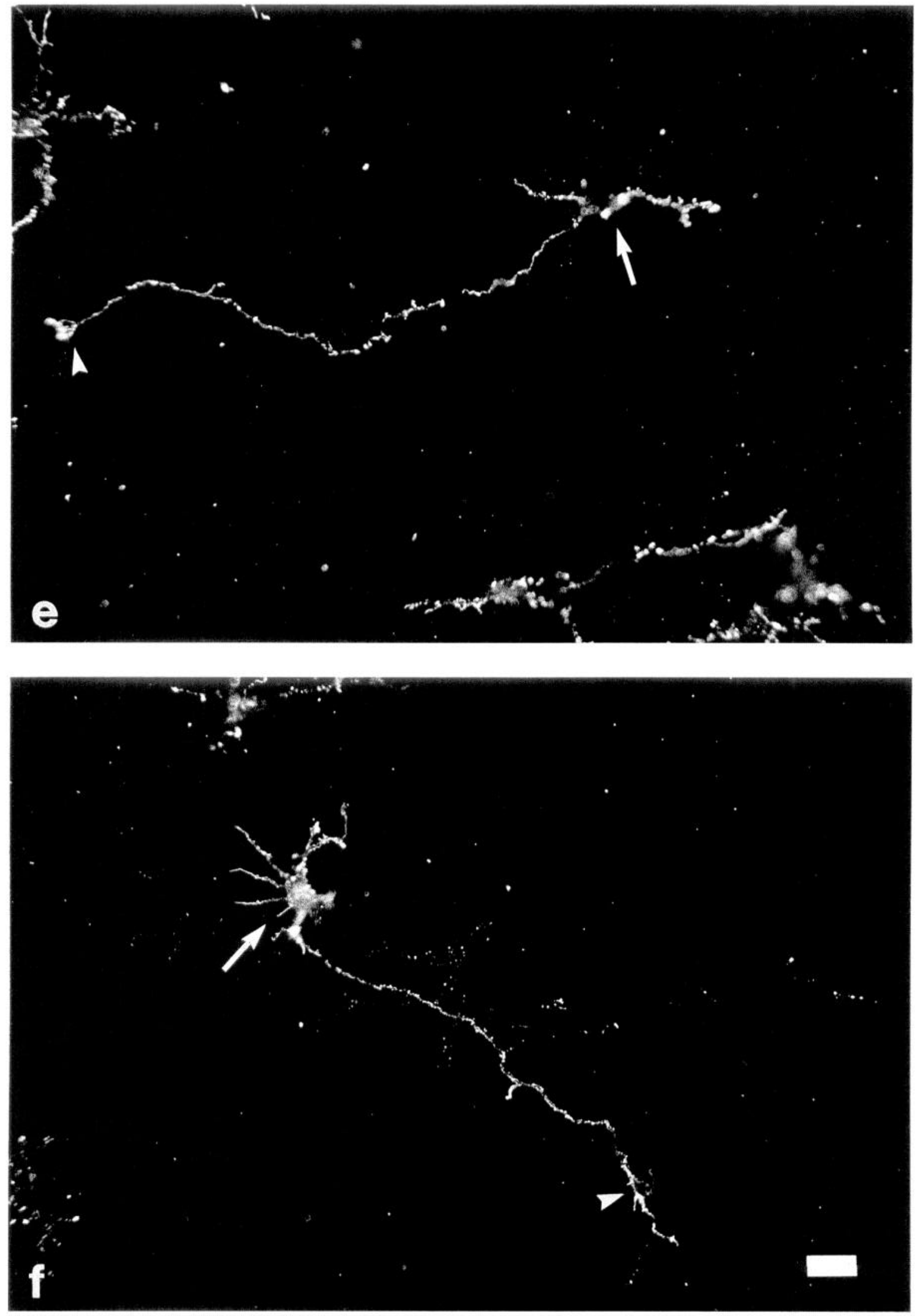
A
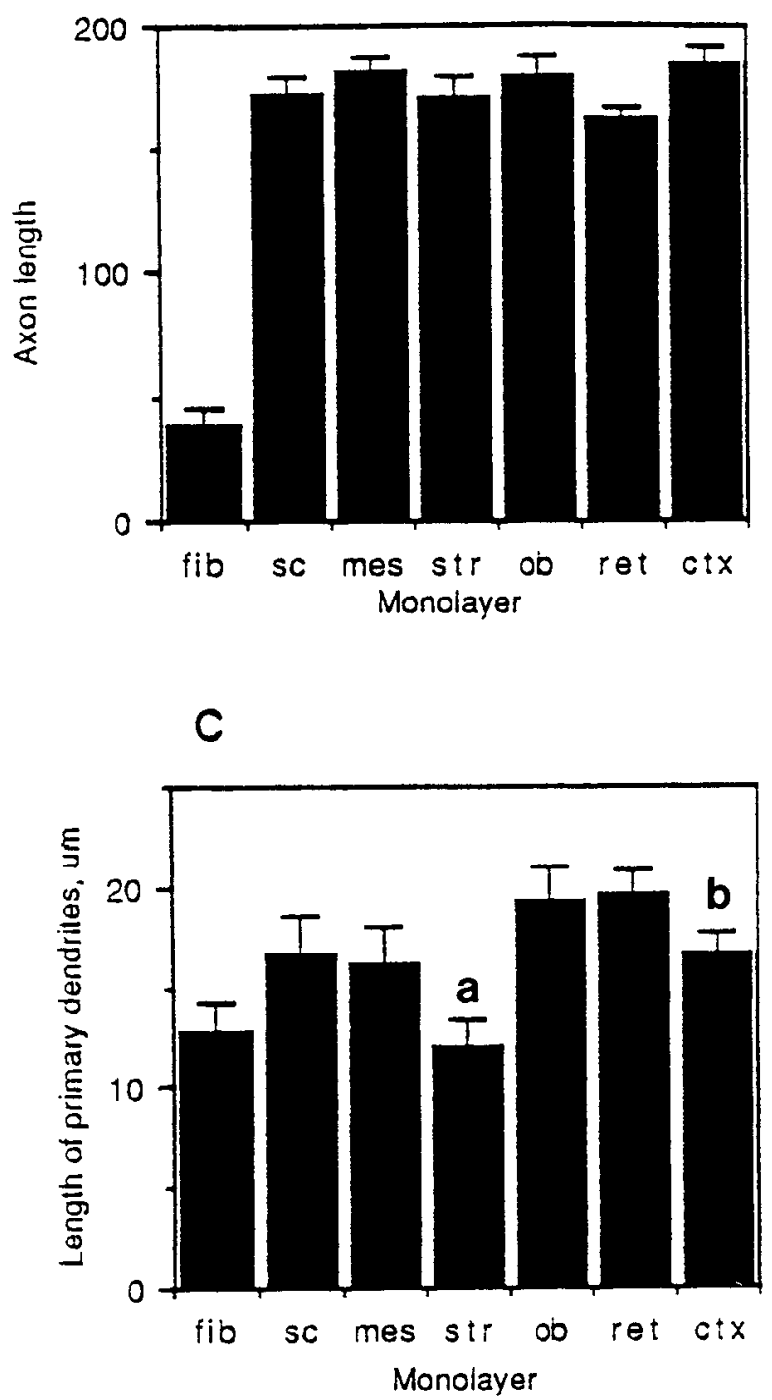

B
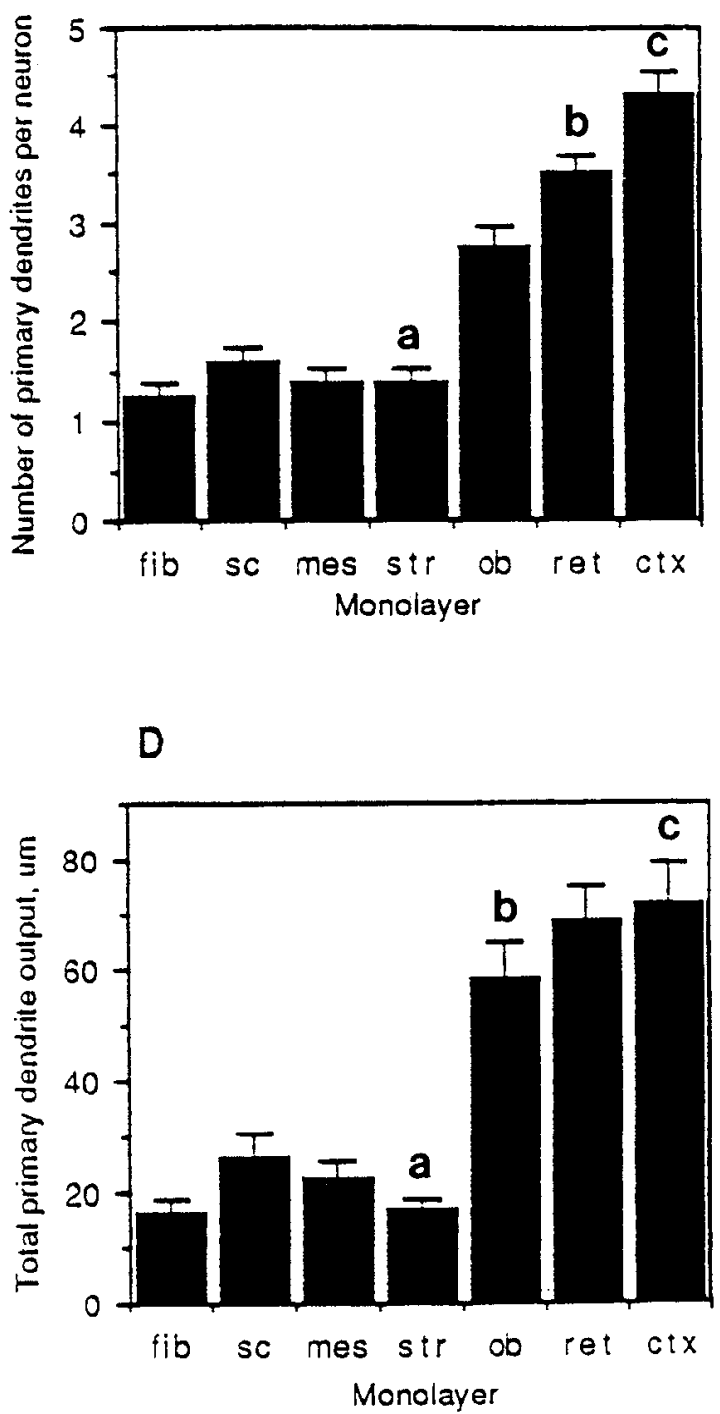

Figure 4. Cortical neuron morphogenesis can be selectively influenced by astroglial cells in culture: histograms illustrating axonal length (a), primary dendrite number $(b)$, primary dendrite length $(c)$, and total dendrite output $(d)$ from mouse cortical neurons cocultured with rat glia derived from different CNS regions as described in Materials and Methods. Neurite elaboration was examined in 100 randomly selected neurons growing on each glial monolayer using quantitative analysis and double-labeling immunohistochemical techniques. Values represent the mean $\pm \mathrm{SEM}$. $f b$, included as control for Student's $t$ test but not for ANOVA. Whereas axonal length was similar on all monolayers tested (ANOVA $p>0.05$ ), total output of primary dendrites was threefold greater on glia derived from cortex, retina, or olfactory bulb than for glia from other CNS regions (ANOVA $p<0.001 ; a=p>0.05$ vs fib, mes, sc; $b=p<0.0001$ vs fib, sc, mes, str; $c=p>0.1$ vs ob, ret). An increase in the number of primary dendrites (ANOVA $p<0.001 ; a=p>0.1$ vs fib, mes, sc; $b=p<0.0001$ vs lib, sc, mes, str; $c=p<0.01$ vs ob, ret) and, to a lesser extent, elongation of individual dendrites ( $a=p>0.05 \mathrm{vs} \mathrm{fib}, \mathrm{sc}$, mes, ctx, $p<0.01 \mathrm{vs} \mathrm{ob}$, ret; $b=p>0.05$ vs fib, sc, ret) observed from cortical neurons were dependent on the source of glial cells. fib, fibroblasts from meninges; $s c$, spinal cord; mes, mesencephalon; str, striatum; $o b$, olfactory bulb; ret, retina; $c t x$, cortex.

dendritic output, the total extent of the primary dendritic arbor was quantified. The results indicated that $21.7 \%$ of the cortical neurons cocultured with cortical astrocytes had primary dendritic arbors with lengths greater than $100 \mu \mathrm{m}$. Extensive primary dendrite elaboration was also observed from cortical neurons that were cocultured with olfactory bulb or retinal glia; $12 \%$ and $16.7 \%$ of neurons achieved arbors greater than 100 $\mu \mathrm{m}$, respectively. By contrast, total primary dendritic elaboration only exceeded $50 \mu \mathrm{m}$ on $8 \%, 0 \%$, and $13.6 \%$ of mesencephalic, striatal, or spinal cord astroglial monolayers, respectively (Fig. 4). Mean total primary dendritic outgrowth was greatest on glia derived from cortex, olfactory bulb, or retina and was nearly threefold greater than that observed on glia from striatum, mesencephalon, or spinal cord (ANOVA $p<0.001$; Fig. 4). These observations indicate that astroglia demonstrate regional differences, although not exclusively region or target specific, in their ability to support cortical neuron dendrogenesis. This effect is principally on dendrite number and total dendrite output, rather than on elongation of individual dendrites.

\section{Axon length does not differ on glial cells from diverse CNS regions}

Antibodies directed against NF-H stained only one neurite emerging from the cell body. The process with $\mathrm{NF}-\mathrm{H}$ immu- 
noreactivity was usually the longest process in both multipolar and bipolar cells. In unipolar cells, the cell body expressed MAP2 whereas the process was usually immunoreactive only for NF$H$. Occasionally, neurites were observed to be immunoreactive for both MAP2 (proximally) and NF-H (along the entire length of the process). These neurites were classified as axons. Since the mouse neurons were plated at low density, the entire length of individual axons could be followed and quantified. Axons tended to follow a meandering course from the cell body and virtually all axons had a growth cone at their tips (Fig. 3e,f). Axonal length of cortical neurons did not differ significantly when plated on the various glial monolayers; $86.8-100 \%$ of axons examined were greater than $130 \mu \mathrm{m}$ and $38-61.5 \%$ were greater than $170 \mu \mathrm{m}$ in length. There was a tendency for greater axonal lengths from cells cultured on cortical astrocytes; however, the difference was not statistically significant (ANOVA $p$ $>0.05$; Fig. 4). The shortest axons were observed on Müller glia; less than $10 \%$ achieved lengths greater than $200 \mu \mathrm{m}$, whereas on other glia between $18.2 \%$ and $35.2 \%$ of axons were greater than $200 \mu \mathrm{m}$ in length.

These immunohistochemical data indicate that astroglial cells derived from cortex, retina, and olfactory bulb allowed initiation and growth of axons and dendrites from mouse cortical neurons in vitro, while astroglial cells derived from striatum, mesencephalon, and spinal cord supported axon growth, but only limited dendrite elaboration.

\section{Diffusible factors released by astrocytes may account for part of the regional differences observed in dendrite growth}

Do the observed differences in the capabilities of astroglia to support dendrite growth reflect specific cell-surface interactions, or differences in soluble factors released by glia? In the next series of experiments, we compared the number and length of neurites from cortical neurons grown on glial monolayers with those grown in a noncontact coculture system in which the glia continuously conditioned the media. Embryonic mouse cortical neurons were plated at low density $\left(1 \times 10^{4}\right.$ cells $\left./ \mathrm{ml}\right)$ directly onto polylysine coverslips in a chemically defined media. Astroglial cells derived from different CNS regions were grown on a millipore filter above and separate from the polylysine coverslips.

After $5 \mathrm{~d}$ in vitro, neurons exhibited regional morphological differences similar to the differences that were described in the previous section. The majority of neurons grown in the presence of cortical, retinal, or olfactory bulb glia were multipolar, whereas neurons grown under spinal cord, mesencephalon, or striatal glia monolayers were typically unipolar or bipolar. Significant differences in the number of primary dendrites from cortical neurons were observed, depending on the CNS source of the glia (ANOVA $p<0.001$; Table 3, Fig. 5). In media conditioned by cortical or retinal astroglia, $72.2 \%$ and $76.5 \%$, respectively, of neurons examined had three or more dendrites. By contrast, $0 \%, 6.6 \%$, and $3.8 \%$ of neurons grown with media conditioned by striatal, mesencephalon, or spinal cord glia, respectively, elaborated three or more dendrites. Olfactory bulb glia-conditioned media had an intermediate effect; $25 \%$ of neurons demonstrated three or more dendrites. Interestingly, the length of individual primary dendrites from cortical neurons did not differ significantly between the different glial monolayers; however, an average $15-25 \%$ reduction was observed when dendrite length in conditioned media was compared to dendrite length in direct coculture. Although total primary dendritic elaboration was less
Table 3. The number of primary dendrites elaborated by cortical neurons depends on the origin of the glia

\begin{tabular}{|c|c|c|c|c|c|c|}
\hline \multirow[b]{2}{*}{ Monolayer } & \multicolumn{6}{|c|}{$\%$ MAP2 + neurites } \\
\hline & 0 & 1 & 2 & 3 & 4 & $>4$ \\
\hline FID $c c$ & 14.3 & 47.6 & 38.1 & 0 & 0 & 0 \\
\hline FIB mp & 23.8 & 61.9 & 9.5 & 0 & 4.8 & 0 \\
\hline $\mathrm{SC} \mathrm{cc}$ & 0 & 54.5 & 31.8 & 13.6 & 0 & 0 \\
\hline $\mathrm{SC} \mathrm{mp}$ & 3.7 & 53.3 & 30.7 & 3.8 & 0 & 0 \\
\hline MES cc & 0 & 65.4 & 26.6 & 6.6 & 0 & 0 \\
\hline MES mp & 13.3 & 53.3 & 26.6 & 6.6 & 0 & 0 \\
\hline STR cc & 0 & 66.6 & 33.3 & 0 & 0 & 0 \\
\hline STR mp & 0 & 81.3 & 18.8 & 0 & 0 & 0 \\
\hline $\mathrm{OB} \mathrm{cc}$ & 0 & 9.1 & 36.4 & 31.8 & 13.6 & 9.1 \\
\hline $\mathrm{OB} \mathrm{mp}$ & 0 & 37.5 & 37.5 & 12.5 & 12.5 & 0 \\
\hline RET cc & 0 & 0 & 8.3 & 45.8 & 33.3 & 12.5 \\
\hline RET mp & 5.9 & 5.88 & 11.8 & 23.5 & 41.2 & 11.8 \\
\hline СТХ cc & 0 & 0 & 4.3 & 8.7 & 60.8 & 26.1 \\
\hline CTX mp & 0 & 5.6 & 22.2 & 33.3 & 22.2 & 16.7 \\
\hline
\end{tabular}

Mouse cortical neurons were cocultured with astroglial from different CNS regions as described in Materials and Methods. After 5 DIV, the number of primary MAP2-immunoreactive processes elaborated from 100 random, isolated cortical neurons on each monolayer were examined. The results represent the percentages of neurons with a specified number of MAP2-positive neurites. Although the most primary dendrites were observed on cortical astrocytes, the number of primary dendrites was also observed to increase significantly on retinal and olfactory bulb glia. mp, noncontact coculture; cc, direct coculture; FIB, fibroblasts from meninges; SC, spinal cord; MES, mesencephalon; STR, striatum; OB, olfactory bulb; RET, retina; CTX, cortex.

profuse in continuously conditioned media than in direct coculture, regional heterogeneity was still observed. The greatest amount of primary dendritic growth was observed in media continuously conditioned by glia-derived cortex, retina, and, to a lesser extent, olfactory bulb (ANOVA $p<0.001$; Fig. 5). Taken together, these observations suggest that astroglial cells may release factors into the culture media, which are both generally permissive for neurite growth but can also specifically initiate and maintain primary dendrite growth.

\section{Analysis of neuron survival and morphology}

A critical point in the interpretation of our results is possible selective survival or selection of a subpopulation of neurons, rather than astroglial stimulated neurite outgrowth. To determine whether this is a relevant factor, we assessed neuron survival by examining marked microscopic fields of approximately $1 \mathrm{~mm}^{2}$ at successive time points and by determining neuronal survival at 1,3 , and $5 \mathrm{~d}$ in vitro using both morphological and immunohistochemical techniques. The number of attached cells $3 \mathrm{hr}$ after plating was taken to be $100 \%$. In order to avoid ambiguity, the neuronal cell types were confirmed by immunostaining with the antibody to MAP2. Viable cells had smooth, round to oval somata and neurites that appeared uniform in diameter and smooth in appearance. Nonviable cells had rough, swollen, and vacuolated somata and irregular, fragmented, or beaded neurites. There was some variation in neuron survival at $5 \mathrm{~d}$ in vitro among the monolayers prepared from different CNS regions, from $41 \%$ in striatum and retina to $48 \%$ for olfactory bulb and spinal cord (ANOVA $p<0.001$; Fig. 6); this variation, however, did not correlate with the observed differences in process growth.

To determine whether astroglia from different CNS regions selectively promoted survival of particular neuronal subpopu- 
A

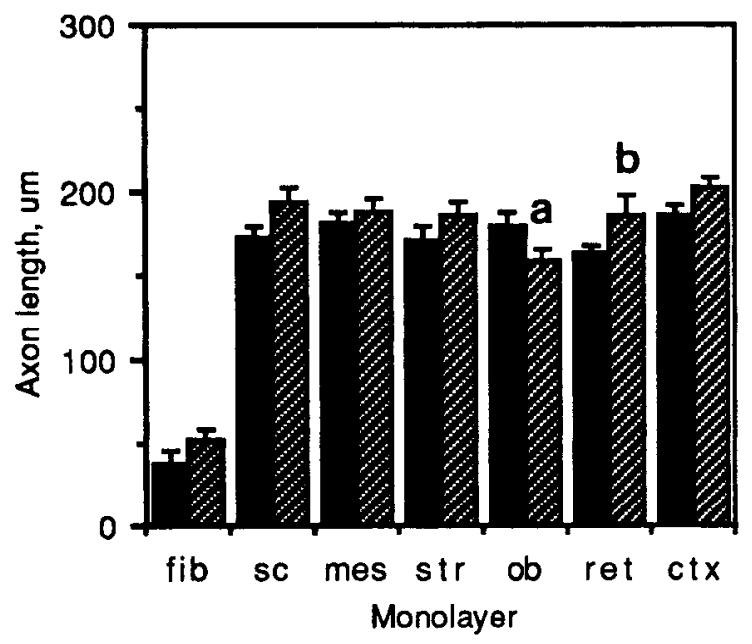

C

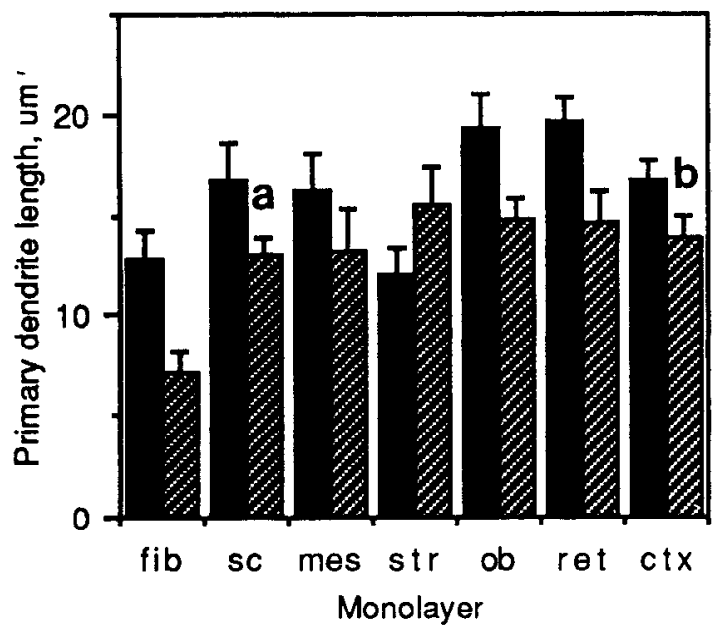

B

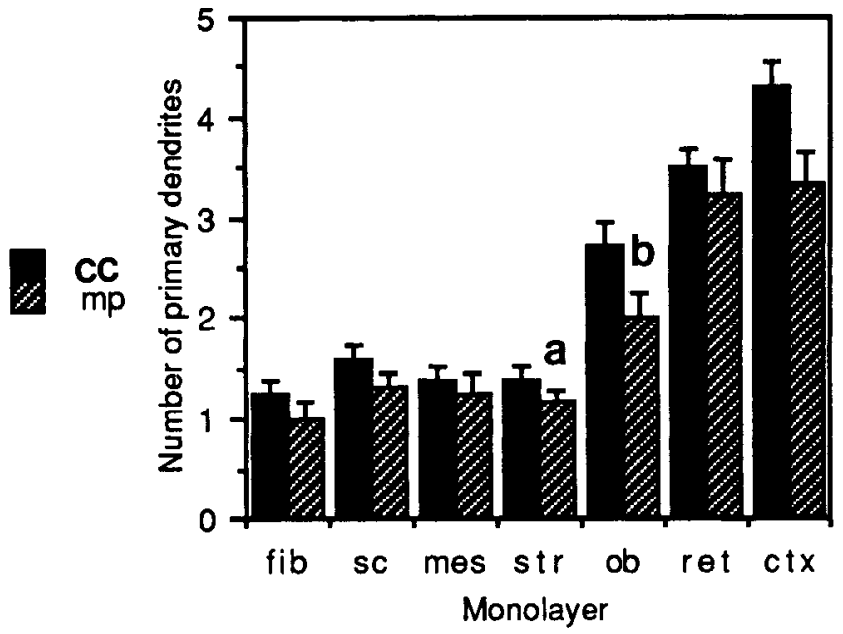

D

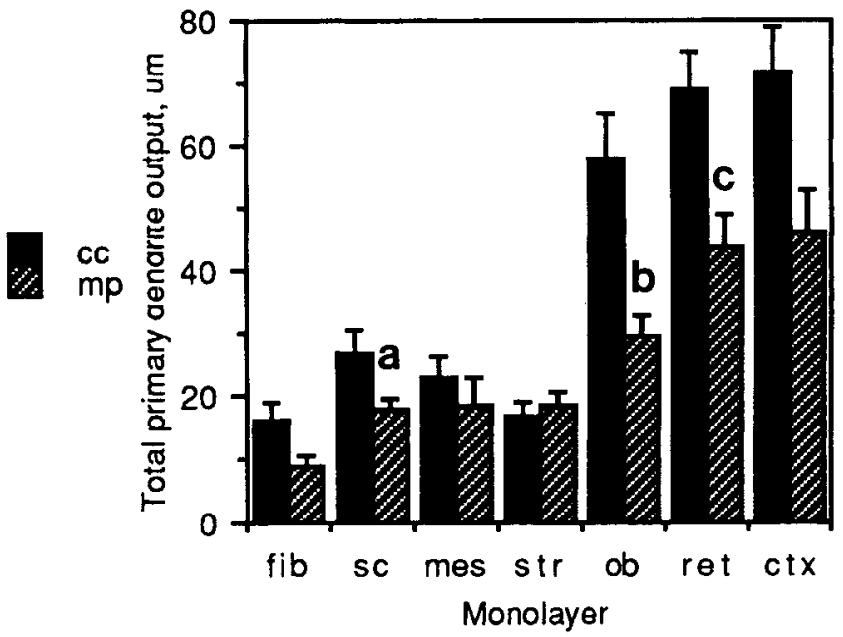

Figure 5. Cortical neuron dendrite growth is, in part, regulated by a diffusible factor released by astroglia. Mouse cortical neurons were grown in a noncontact coculture system in which the media were continuously conditioned by glial monolayers derived from various $\mathrm{CNS}$ regions. After 5 DIV axonal length $(a)$, primary dendrite number $(b)$, dendritic length $(c)$, and total primary dendritic output $(d)$ were quantified from 100 randomly selected neurons for each glial subtype. Results represent the mean \pm SEM. fib, included as control for Student's $t$ test but not for ANOVA. Noncontact $(m p)$ and direct coculture $(\mathrm{cc})$ are compared. In continuously conditioned media $(\mathrm{mp})$, regional heterogeneity in glial-mediated axonal growth was not observed with the exception of olfactory bulb glia $(a=p<0.0001 \mathrm{vs} \mathrm{fib,} p<0.05 \mathrm{vs} \mathrm{sc}$, mes, str, ret, ctx; $b=p>0.05 \mathrm{vs}$ sc, mes, str, ctx). By contrast, dendrite output depended on the region from which the glia were derived. Although primary dendrite elaboration was less prolific in continuously conditioned media $(\mathrm{mp})$ than in direct coculture $(\mathrm{cc})$, greater total primary dendritic output (ANOVA $p<0.001, a=$ $p<0.05$ vs fib, $p<0.01$ vs ob, $p>0.5$ vs mes, str; $b=p<0.05$ vs ret, ctx; $c=p>0.05$ vs ctx) and, in particular, an increase in the number of primary dendrites (ANOVA $p<0.001 ; a=p>0.5$ vs fib, sc, mes, $p<0.01$ vs ob; $b=p<0.01$ vs ret, ctx) were still observed in the presence of cortical or retinal glia and, to a lesser extent, olfactory bulb glia. The length of individual dendrites $(c)$, unlike direct coculture, did not demonstrate regional differences (ANOVA $p>0.1 ; a=p<0.001$ vs fib, $p>0.05$ vs mes, str, ob, ret, ctx; $b=p>0.05$ vs mes, ret). fib, fibroblasts from meninges; $s c$, spinal cord; mes, mesencephalon; str, striatum; ob, olfactory bulb; ret, retina; $c t x$, cortex.

lations, such as interneurons or projection neurons, we compared the size and morphology of the cell body of neurons plated on the different glial monolayers. Although there was a range in neuronal diameter on each monolayer, mean cell body diameter was virtually identical on all monolayers (Fig. 6). Similarly, no distinct difference in neuron cell body shape was observed. In addition, neurons on all the various monolayers demonstrated axons of similar length (see above). Taken together, these results indicate that the effect on process outgrowth on the various glial monolayers was specific rather than medi- ated through selective survival of a distinct neuronal subpopulation or a selective influence on neuronal survival.

\section{Discussion}

Our data are consistent with and extend previous observations that astroglia can selectively modulate the morphologic development of neurons in culture. First, dendrite number, total primary dendrite output and, to a lesser degree, length of individual dendrites from mouse cortical neurons in vitro were greater when cortical neurons were placed on glia from cortex, retina, and 
A

\begin{tabular}{||l|c|c|c||}
\hline Monolayer & \multicolumn{1}{|c|}{ DIV } & 30IV & 50IV \\
\hline Fibroblast & $68.6 \pm 3.3$ & $52.9 \pm 5.6$ & $38.8 \pm 2.5$ \\
\hline Spinal Cord & $81.6 \pm 2.8$ & $66.5 \pm 3.1$ & $48.1 \pm 2.7$ \\
\hline Mesencephalon & $81.1 \pm 4.7$ & $64 \pm 3.6$ & $43.8 \pm 3.2$ \\
\hline Striatum & $80.4 \pm 4.1$ & $63.2 \pm 5.3$ & $41.5 \pm 3.3$ \\
\hline Olfactory buib & $80.8 \pm 2.7$ & $59.6 \pm 3.2$ & $48.4 \pm 4.3$ \\
\hline Retina & $82.4 \pm 4.7$ & $63.3 \pm 3.7$ & $41.7 \pm 4.3$ \\
\hline Cortex & $83.6 \pm 3.8$ & $60.8 \pm 3.1$ & $44.9 \pm 2.5$ \\
\hline
\end{tabular}

B

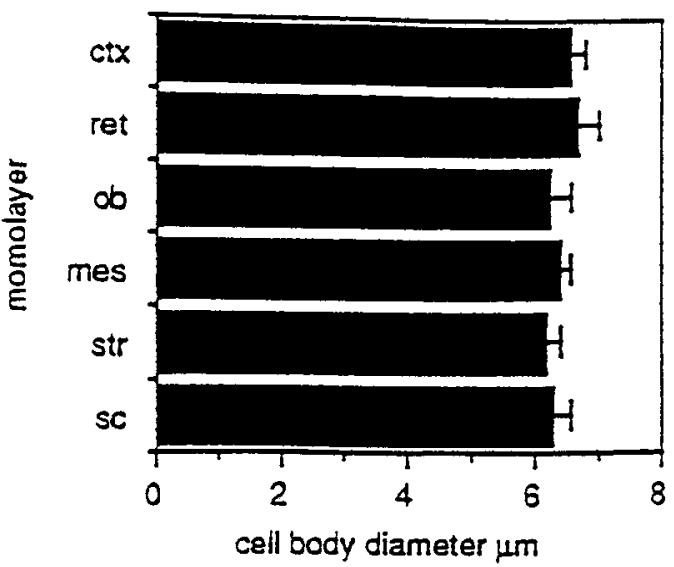

Figure 6. Neuron survival and cell body diameter. A, Cortical neuron survival varies among different glial monolayers but does not correlate with dendrite outgrowth. Neurons were plated at $1 \times 10^{4} \mathrm{cells} / \mathrm{ml}$ in the presence of glia derived from various regions of the CNS and neuron viability determined with morphologic and immunohistochemical techniques at 1,3 , and 5 DIV. Values for neuronal survival are expressed as the percentage of the original number of viable neurons at $3 \mathrm{hr}$ in culture and represent the mean \pm SEM. Six random microscopic fields on five coverslips were examined in three separate cultures of each glial subtype. Fibroblasts and polylysine represent controls. Although glia had a clear effect on survival and variance was observed among the various glial subpopulations (ANOVA $p<0.001$ ), the extent of dendritic elaboration was independent of this effect. $B$, Glia derived from different $C N S$ regions do not select subpopulations of cortical neurons: histograms illustrating mouse cortical neuron cell body diameter. Embryonic neurons were cocultured with glia for $5 \mathrm{~d}$ and examined after labeling with M6 or MAP2. Although there was a tendency for neurons with more dendrites to appear larger, quantitative analysis did not demonstrate a difference in neuron cell body diameter on the different glial monolayers tested (between group ANOVA $p>0.1)$. Values represent the mean \pm SEM $(n=100$ neurons for each glial subtype). $f i b$, fibroblasts from meninges; $s c$, spinal cord; mes, mesencephalon; str, striatum; $o b$, olfactory bulb; ret, retina; $c t x$, cortex.

olfactory bulb than when plated on glia derived from mesencephalon, striatum, or spinal cord. Although homotypic glia are not the exclusive source for promotion of cortical neuron dendritic outgrowth, they are among the most effective glia for stimulating dendrite elaboration. Second, axonal growth was similar on all the glial monolayers that were tested. Striatal, mesencephalic, spinal cord, and even cortical glia may be regarded as target glia for cortical neurons. Cortical neurons, however, do not project to either the retina or olfactory bulb; thus, target glia alone do not appear to promote selectively axonal growth from cortical neurons in vitro. Third, neurons grown in media conditioned by glia exhibited regional morphological differences, depending on the CNS source of the glia. We propose, thercfore, that for mouse cortical neurons in vitro, (1) axonal and dendritic growth are separately regulated, (2) glia from different CNS regions differ in their ability to support the outgrowth of primary dendrites, though not in an exclusively homotypic manner, and (3) certain astroglia release a factor or factors that can specifically modulate primary dendrite outgrowth.

\section{Astroglia influence the number of primary dendrites}

In what way do glia modulate neurite growth from cortical neurons? Our results suggest the interesting possibility that glia can specifically regulate or maintain the number of primary dendrites that are elaborated by neurons. Although in vitro studies have demonstrated that neurons may have an intrinsic ability to initiate dendrites and axons (Bartlett and Banker, 1984), other studies have provided evidence that dendritic growth of a neuron can be influenced by interactions with other cells. In vitro studies of both the autonomic nervous system and CNS indicate that differences in glia modulation of neurite outgrowth are primarily manifested in the number of neurites elaborated and, to a lesser extent, in the degree of branching or elongation (Denis-
Donini et al., 1984; Chamak et al., 1987; Autillo-Touati et al., 1988; Rousselet et al., 1988, 1990; Tropea et al., 1988; Johnson et al., 1989; Qian et al., 1992). The final form that dendrites develop, including their secondary and tertiary branches, may also be supported by astroglia but, in part, may be further influenced by neuronal activity (Wise et al., 1979; Hammer et al., 1981; Petit et al., 1988; Mattson et al., 1988; Schilling et al., 1991).

This selective promotion of dendrite number has been argued as a basis for homotypic influences of glia on neurons. For example, Chamak et al. (1987) observed a greater number of MAP2-immunoreactive neurites from mesencephalic neurons in the presence of homotypic glia than when cocultured with striatal glia. The change in the mean number of neurites per neuron, however, although significant, was small: approximately 1.5 dendrites per neuron on striatal glia versus two on mesencephalic glia. It is possible, therefore, that the differences observed by Chamak et al. (1987) may, in part, be explained by the relative abilities of striatal or mesencephalic glia to support dendrite growth, rather than a specific homotypic influence. In addition, other studies have failed to find an exclusively homotypic pattern of glial-mediated neurite outgrowth. For example, Qian et al. (1992) reported that the length and number of primary dendrites from spinal cord neurons were similar, when cocultured with either spinal cord or cerebellar glia. Our results confirm that there are substantial regional differences in the ability of glia to promote dendritic outgrowth, but that these differences do not follow exclusively homotypic lines.

Could the maturational state of astroglial cells in the various monolayers account for our observations? Experiments both in vitro and in vivo indicate that mature astrocytes have a reduced capacity to support neurite, but not specifically dendrite, growth when compared with immature astrocytes (Smith et al., 1986, 
1990). The relative degree of astrocyte maturation is likely to vary in different regions of the CNS at any particular developmental time (Edwards et al., 1990; Landry et al., 1990). However, it is unlikely that this is the sole explanation for the differences we have observed in the ability of glia to promote dendritic growth. Vimentin expression, typically expressed by immature astrocytes (Dahl, 1981; Prochiantz et al., 1982; Bovolenta et al., 1984; Dupouey et al., 1985; Frederiksen and McKay, 1988; see Cameron and Rakic, 1991, for review) did not correlate with the ability of the glia to support dendrite growth. Although robust dendritic growth was observed on glial monolayers that contained a relatively high percentage of vimentinimmunoreactive cells, such as cortical glia, neurons plated on monolayers with a similar percentage of vimentin-immunoreactive cells, such as striatal glia, had a limited dendritic arbor. A similar conclusion was reached by Chamak et al. (1987), who did not find substantial differences in the number of MAP2immunoreactive processes from embryonic mesencephalic neurons when cocultured with embryonic (E15 or E18) or postnatal glia (P4).

\section{Glial origin does not determine axon length}

We have found that glia from all regions of the CNS that we tested support axonal growth to a similar extent. This finding is, in part, consistent with previous investigations in vitro that indicate that axonal growth appears to continue even in conditions that do not support dendrite growth (Autillo-Touati et al., 1988; Bruckenstein and Higgins, 1988; Rousselet et al., 1988, 1990). In addition, other studies have found that glia are generally a favorable substrate for neurite outgrowth (Noble et al., 1984; Fallon, 1985).

There is some evidence that target-derived glia may promote axonal growth. For example, Qian et al. (1992) observed enhanced axonal growth when spinal cord neurons were cultured in the presence of, but not in direct contact with, cerebellar glia compared to glia from other CNS sources. Similarly, they observed enhanced axonal growth from hippocampal neurons cultured with cortical glia when compared to hippocampal glia. They concluded that target-derived glia specifically promote axon growth and that axons are more sensitive than dendrites to factors released by glia. Some support for this contention is provided by Prochiantz and colleagues (Rousselet et al., 1990). Although these investigators observed a more noticeable effect of homotypic glia on dendrite number, they also found that axon length was different depending on whether mesencephalic neurons were cultured with media conditioned by striatal glia (mean length, $173.2 \pm 5.7 \mu \mathrm{m}$ ) or mesencephalic glia (mean length, $116.8 \pm 3.7 \mu \mathrm{m})$. This result is consistent with the proposal by Qian et al. (1992), since the striatum is a target of certain neurons in the mesencephalon. In an earlier study, however, the same investigators (Rousselet et al., 1988) observed that total neurite length from mesencephalic neurons was greatest in homotypic and not target-derived (striatal) glial-conditioned media. The observation by Denis-Donini and Estenoz (1988) further complicates a simple interpretation. The primary mesencephalic neurons that project to the striatum are the dopaminergic neurons of the substantia nigra. These investigators spccifically cxamincd this population of cells and obscrved that dopaminergic mesencephalic neurons had shorter neurites when cultured on striatal (target) glia than homotypic glia. The longest neurite outgrowth occurred on olfactory bulb glia, a nontarget, nonhomotypic source of glia. Axons, however, were not specifically identified.

In our study, the retina and olfactory bulb cannot be regarded as targets for cortical neurons, yet axon length was the same on these monolayers when compared to target-derived glia such as striatum, mesencephalon, or even spinal cord. Thus, for cortical neurons at least, glial heterogeneity and, in particular, targetderived glia do not appear to influence axon length selectively in vitro. The apparent discrepancy between our results and those of Qian et al. (1992) and Rousselet et al. (1990) may, in part, be explained by our selection criteria. We only analyzed neurons that were not in synaptic contact with other neurons and may therefore have excluded axons from long projection neurons that are more likely to be in contact with other neurons. In addition, the small neuron cell bodies that we observed indicate that our sample may have included primarily nonprojection neurons. It is therefore possible that the glial factors that stimulate axon growth may be different for projection and nonprojection neurons. This possibility has not been addressed by any study to date and needs further investigation.

\section{Astroglial heterogeneity}

Although no obvious morphologic differences were observed between glial monolayers derived from different CNS regions, there is increasing evidence that more subtle biochemical differences exist between the different glia. Astrocytes from different anatomic regions have been found to express characteristic ion channel phenotypes, adhesive properties, and neurotransmitter receptors (for review, see Hansson, 1988; Barres, 1991). Mesencephalic or striatal astrocytes in vitro synthesize and express distinct glycoproteins on their surface (Barbin et al., 1988). In addition, specific posttranslational modifications or alternate mRNA splicing resulting in multiple isoforms of the same molecule may also play a role in generating functional heterogeneity among astrocytes. Support for this hypothesis has been demonstrated by LaFont et al. (1992), who observed that embryonic neuron polarity can be mediated by dermatan sulfate proteoglycan, but not other proteoglycans, and that this function was dependent on the specific sugar moiety expressed rather than the protein epitope.

A variety of studies indicate that neurotrophic factors support neurite growth from central neurons (Walicke et al., 1986; Hatten et al., 1988; Mattson et al., 1989; Kawaja and Gage, 1991). Our results indicate that, in part, dendrite growth is modulated by a diffusible factor. Could the functional diversity of astroglia, therefore, be secondary to specific localization of these substances? Immunohistochemical reactivity or mRNA expression of several growth factors including bFGF (Ferrara et al., 1988; Finklestein et al., 1988; Gonzalez et al., 1990; Gómez-Pinilla et al., 1992; Logan et al., 1992; Woodward et al., 1992), NGF (Furukawa et al., 1986; Lu et al., 1991; Saad et al., 1991; Yoshida and Gage, 1991; Zafra et al., 1992), EGF (Gómez-Pinilla et al., 1988; Nieto-Sampedro et al., 1988), IGF (Rotwein et al., 1988; Garcia-Estrada et al., 1992), PDGF (Mapstone, 1991; Yeh et al., 1991), and cytokines such as TGF (Fallon et al., 1990; Wesselingh et al., 1990; Saad et al., 1991) and IL-1 (Wesselingh et al., 1990) have been detected in astroglial cells both in vitro and in vivo. None of these studies, however, determined whether there are regional differences in synthesis, expression, or release of growth factors from astroglial cells. Recently, Lazar and Blum (1992), using a solution hybridization ribonuclease protection assay, demonstrated that the expression of EGF mRNA exhib- 
ited regional variation in the brain. It is thus conceivable that astrocytes in specific regions of the brain express or synthesize different concentrations or isoforms of growth factors.

Are therc any similarities between cortex, olfactory bulb, and retina that might explain their selective ability to promote dendrite growth? All are derived from the prosencephalon and are composed primarily of gray matter. Nevertheless, we observed little dendrite growth on striatal astrocytes, which are also derived from the prosencephalon and composed of gray matter. Thus, a common embryological site of origin or the relative amount of gray/white matter are unlikely explanations for the differences. One possible explanation is the interesting similarity in the basic architecture and circuitry of the three regions. The cortex, olfactory bulb, and retina are all, to some extent, laminar structures composed of vertical pathways with numerous horizontal pathways that integrate the vertical signals. Thus, it is conceivable that glia and/or neurons of these regions share common structures, surface molecules, or receptors that permit glialmediated dendrite growth that is not entirely region specific.

\section{Mechanism of astrocyte-mediated dendrite growth}

Axonal and dendritic growth appear to be dissociable events and, at least in part, separately regulated. Regardless of the reason for glia heterogeneity in promoting dendrite outgrowth, an important issue is whether dendrite elaboration is solely dependent on molecules associated with the cell surface or regulated by soluble factors. Our findings suggest that, at lcast in part, glia-mediated dendrite growth, independent of axonal growth, is promoted by a diffusible factor. This is the first direct evidence that glia may release a factor or factors that can selectively modulate dendritic morphology in the CNS; whether this is a novel factor or a known factor with a novel function is currently not known. Consistent with this is the recent finding by De Konnick et al. (1993) that nerve growth factor (NGF) induces an increase in dendrite outgrowth, but has little effect on axon growth from neonatal rat sensory neurons.

There is considerable evidence that glial cells secrete diffusible neurite-promoting factors (Hatten et al., 1988; Rousselet et al., 1988, 1990; Qian et al., 1992). For example, media conditioned on homotypic glia can enhance polarity of embryonic mouse mesencephalic neurons in primary culture (Rousselet et al., 1988, 1990). Similarly, Seil et al. (1992) have observed that media conditioncd by cercbellar astrocytes promote the development of Purkinje cell dendritic spines. The precise molecular nature of the factor or factors responsible is not known, although protein degradation studies indicate that they are proteins or require protein cofactors. While previously identified soluble peptide growth factors have been observed to promote neurite outgrowth from CNS neurons, none of these studies has reported selective effects on the growth of either axons or dendrites (Hatten et al., 1988; Rousselet et al., 1988; Lein and Higgins, 1989; Mattson et al., 1989).

The simplest explanation of our data is that glia release a diffusible factor(s) that can specifically mediate dendrite growth independent of axon growth. This factor could be labile or easily degraded in media, explaining the less prolific dendrite growth observed in glia-conditioned media. Alternatively, close cell contact might provide a higher concentration of the factor(s). Other plausible explanations include the possibility that factors released by glia interact with molecules associated with the extracellular matrix or, alternatively, that soluble factors regulate or directly promote cell adhesion of growth cones in a process- specific manner (Seilheimer et al., 1987; Burgess and Maciag, 1989; Rossino et al., 1990; Flanagan et al., 1991; Yayon et al., 1991; Damsky and Werb, 1992; Doherty et al., 1992; Doherty and Walsh, 1992; Thiery and Boyer, 1992).

An important role for astroglia in modulation of dendrite growth does not exclude other mechanisms but rather emphasizes the complex integrative nature of the CNS. Further experiments will be necessary to elucidate the mechanism of gliamediated dendrite growth. From the present experiments it is apparent not only that glia mediate dendrite growth in a regionspecific manner, but that certain glia may regulatc spccific process outgrowth from cortical neurons independent of their anatomic origin. In part, diffusible factors may regulate glia-mediated dendrite growth in collaboration with molecules associated with the cell surface or matrix.

\section{References}

Autillo-Touati A, Chamak B, Araud D, Vuillet J, Seite R, Prochiantz A (1988) Region-specific neuro-astroglial interactions: ultrastructural study of the in vitro expression of neuronal polarity. J Neurosci Res 19:326-342.

Baird DH, Hatten ME, Mason CA (1992) Cerebellar target neurons provide a stop signal for afferent neurite extension in vitro. J Neurosci 12:619-634.

Barbin G, Katz DM, Chamak B, Glowinski J, Prochiantz A (1988) Brain astrocytes express region-specific surface glycoproteins in culture. Glia 1:96-103.

Barres BA (1991) New roles for glia. J Neurosci 11:3685-3694.

Bartlett WP, Banker GA (1984) An electron microscopic study of the development of axons and dendrites by hippocampal neurons in culture. 1. Cells which develop without intercellular contacts. J Neurosci 4:1944-1953.

Bovolenta P, Liem RKH, Mason CA (1984) Development of cerebellar astroglia: transitions in form and cytoskeletal content. Dev Biol 102:248-259.

Bruckenstein DA, Higgins D (1988) Morphological differentiation of embryonic rat sympathetic neurons in tissue culture. 1. Conditions under which neurons form axons but not dendrites. Dev Biol 128: 324-336.

Burgess WH, Maciag R (1989) The heparin-binding (fibroblast) growth factor family of proteins. Annu Rev Biochem 58:575-606.

Cáceres A, Banker G, Steward O, Binder L, Payne M (1984) MAP2 is localized to the dendrites of hippocampal neurons which develop in culture. Dev Brain Res 13:314-318.

Cáceres A, Banker GA, Binder L (1986) Immunocytochemical localization of tubulin and microtubule-associated protein 2 during the development of hippocampal neurons in culture. J Neurosci 6:714 722.

Cameron RS, Rakic P (1991) Glial cell lineage in the cerebral cortex: a review and synthesis. Glia 4:124-137.

Chamak B, Fellans A, Glowinski J, Prochiantz A (1987) MAP2 expression and neuritic outgrowth and branching are correlated through region-specific neuroastroglial interactions. J Neurosci 7:3163-3170.

Dahl D (1981) The vimentin-GFA protein transition in rat neuroglia cytoskeleton occurs at the time of myelination. J Neurosci Res 6:741748

Damsky CH, Werb Z (1992) Signal transduction by integrin receptors for extracellular matrix: cooperative processing of extracellular information. Curr Opin Cell Biol 4:772-781.

Deitch JA, Rubel EW (1984) Afferent influences on brain stem auditory nuclei of the chicken: time course and specificity of dendritic atrophy following deafferentation. J Comp Neurol 229:66-79.

De Konnick P, Carbonetto S, Cooper E (1993) NGF induces neonatal rat sensory neurons to extend dendrites in culture after removal of satellite cells. J Neurosci 13:577-585.

De Leeuw AM, Gaur VP, Saari JC, Milam AH (1990) Immunolocalisation of cellular retinol-, retinaldehyde and retonoic binding proteins in the retina during pre- and postnatal development. J Neurocytol 19:253-264.

Denis-Donini S, Estenoz M (1988) Interneurons versus efferent neurons: heterogeneity in their neurite outgrowth response to glia from several brain regions. Dev Biol 130:237-249. 
Denis-Donini S, Glowinski J, Prochiantz A (1984) Glial heterogeneity may define the three-dimensional shape of mouse mesencephalic dopaminergic neurons. Nature 307:641-643.

Doherty P, Walsh FS (1992) Cell adhesion molecules, second messengers and axonal growth. Curr Opin Neurobiol 2:595-601.

Doherty P, Rimon G, Mann DA, Walsh FS (1992) Alternative splicing of the cytoplasmic domain of neural cell adhesion molecule alters its ability to act as a substrate for neurite outgrowth. J Neurochem 58: 2338-2341.

Dotti CG, Sullivan CA, Banker GA (1988) The establishment of polarity by hippocampal neurons in culture. $J$ Neurosci $8: 1454-1458$.

Doucette R (1990) Glial influences on axonal growth in the primary olfactory system. Glia 3:433-449.

Dupouey P, Benjelloun-Touini D, Gomes D (1985) Histochemical demonstration of an organized cytoarchitecture of the radial glia in the CNS of the embryonic mouse. Dev Neurosci 7:81-93.

Edwards MA, Yamamoto M, Caviness VS Jr (1990) Organization of radial glia and related cells in the developing murine $\mathrm{CNS}$, an analysis based upon a new monoclonal antibody marker. Neuroscience 36 : 121-144.

Fallon JH, Annis CM, Gentry LE, Twardzik DR, Loughlin SE (1990) Localization of cells containing transforming growth factor- $\alpha$ precursor immunoreactivity in the basal ganglia of the adult rat brain. Growth Factors 2:241-250.

Fallon JR (1985) Preferential outgrowth of central nervous system neurites on astrocytes and Schwann cells as compared with non-glial cells in vitro. J Cell Biol 100:198-207.

Ferrara N, Ousley F, Gospodarowicz D (1988) Bovine brain astrocytes express.basic fibroblast growth factor, a neurotrophic angiogenic mitogen. Brain Res 462:223-232.

Finklestein SP, Apostolides PJ, Caday CG, Prosser J, Philips MF, Klagsbrun $M$ (1988) Increased basic fibroblast growth factor (bFGF) immunoreactivity at the site of focal brain wounds. Brain Res 460:253259

Flanagan JG, Chan DC, Leder P (1991) Transmembrane form of the kit ligand growth factor is determined by alternative splicing and is missing in the $S l^{d}$ mutant. Cell 64:1025-1035.

Frederiksen K, McKay RDG (1988) Proliferation and differentiation of rat neuroepithelial precursor cells in vivo. J Neurosci 8:1144-1151.

Furukawa S, Furukawa Y, Satoyoshi E, Hayashi K (1986) Synthesis and secretion of nerve growth factor by mouse astroglial cells in culture. Biochem Biophys Res Commun 136:57-63.

Garcia-Estrada J, Garcia-Segura LM, Torres-Aleman I (1992) Expression of insulin-like growth factor I by astrocytes in response to injury. Brain Res 592:343-347.

Gómez-Pinilla F, Knauer DJ, Nieto-Sampedro M (1988) Epidermal growth factor receptor immunoreactivity in rat brain. Development and cellular localization. Brain Res 438:385-390.

Gómez-Pinilla F. Lee JW-K, Cotman CW (1992) Basic FGF in adult rat brain: cellular distribution and response to entorhinal lesion and fimbria-fornix transection. J Neurosci 12:345-355.

Gonzalez A-M, Buscaglia M, Ong M, Baird A (1990) Distribution of basic fibroblast growth factor in the 18-day rat fetus: localization in the basement membranes of diverse tissues. J Cell Biol 110:753-765.

Ilammer RP, Lindsay RD, Scheibel AB (1981) Development of the brain stem reticular core: an assessment of dendritic state and configuration in the perinatal rat. Dev Brain Res 1:179-190.

Hansson E (1988) Astroglia from defined brain regions as studied with primary cultures. Prog Neurobiol 30:369-397.

Hatten ME, Lynch M, Ryder RE, Sanchez J, Joseph-Silverstein J, Moscattelli D, Rifkin DB (1988) In vitro neurite extension by granule neurons is dependent upon astroglial-derived fibroblast growth factor. Dev Biol 125:280-289.

Johnson MI, Higgins D, Ard MD (1989) Astrocytes induce dendritic development in cultured sympathetic neurons. Dev Brain Res 47: 289-292.

Kawaja MD, Gage FH (1991) Reactive astrocytes are substrates for the growth of adult CNS axons in the presence of elevated levels of nerve growth factor. Neuron 7:1019-1030.

Kosik KS, Finch EA (1987) MAP2 and tau segregate into dendritic and aonal domains after the elaboration of morphologically distinct neurites: an immunocytochemical study of cultured rat cerebrum. J Neurosci 7:3142-3153.

LaFont F, Rouget M, Triller A, Prochiantz A, Rousselet A (1992) In vitro control of neuronal polarity by glycosaminoglycans. Development 114:17-29.
Landry CF, Ivy GO, Brown IR (1990) Developmental expression of glial fibrillary acidic protein $\mathrm{mRNA}$ in the rat brain analyzed by in situ hybridization. J Neurosci Res 25:194-203.

Lazar LM, Blum M (1992) Regional distribution and developmental expression of epidermal growth factor and transforming growth factor- $\alpha$ mRNA in mouse brain by a quantitative nuclease protection assay. J Neurosci 12:1688-1697.

Lein PJ, Higgins D (1989) Laminin and basement membrane extract have different effects on axonal and dendritic outgrowth from embryonic rat sympathetic neurons in vitro. Dev Biol 136:330-345.

Levison SW, McCarthy KD (1991) Astroglia in culture. In: Culturing nerve cells, pp 309-336. Cambridge, MA: MIT Press.

Logan A, Grautschy SA, Gonzalez A-M, Baird A (1992) A time course for the focal elevation of synthesis of basic fibroblast growth factor and one of its high-affinity receptors (flg) following a localized cortical brain injury. J Neurosci 12:3828-3837.

Lu B, Yokoyama M, Dreyfus CF, Black IB (1991) NGF gene expression in actively growing brain glia. J Neurosci 11:318-326.

Lund RD, Chang FLF, Hankin MH, Lagenaur CF (1985) Use of a species-specific antibody for demonstrating mouse neurons transplanted to rat brains. Neurosci Lett 61:221-226.

Mapstone TB (1991) Expression of platelet-derived growth factor and transforming growth factor and their correlation with cellular morphology in glial tumors. J Neurosurg 75:447-451.

Mattson MP, Lee RE, Adams ME, Guthrie PB, Kater SB (1988) Interaction between entorhinal axons and target hippocampal neurons: a role for glutamate in the development of hippocampal circuitry. Neuron 1:865-876.

Mattson MP, Murrain M, Guthrie PB, Kater SB (1989) Fibroblast growth factor and glutamate: opposing roles in the generation and degeneration of hippocampal neuroarchitecture. J Neurosci 9:37283740 .

Matus A, Bernhardt R, Bodner R, Alaimo-Beuret D (1986) Microtubule-associated protein 2 and tubulin are differently distributed in the dendrites of developing neurons. Neuroscience 12:371-389.

Neugebauer KM, Tomaselli KJ, Lilien J, Reichardt LF (1988) N-cadherin, NCAM and integrins promote retinal neurite outgrowth on astrocytes in vitro. J Cell Biol 107:1177-1187.

Nieto-Sampedro M, Gómez-Pinilla F, Knauer DJ, Broderick JT (1988) Epidermal growth factor receptor immunoreactivity in rat brain astrocytes. Response to injury. Neurosci Lett 91:276-282.

Noble M, Fok-Seang J, Cohen J (1984) Glia are a unique substrate for the in vitro growth of central nervous system neurons. J Neurosci 4:1892-1903.

Norris CR, Kalil K (1991) Guidance of callosal axons by radial glia in the developing cerebral cortex. J Neurosci 11:3481-3492.

Pennypacker K. Fischer I, Levitt P (1991) Early in vitro genesis and differentiation of axons and dendrites by hippocampal neurons analyzed quantitatively with neurofilament- $\mathrm{H}$ and microtubule-associated protein 2 antibodies. Exp Neurol 111:25-35.

Petit TL, LeBoutillier JC, Gregorio A, Libstug H (1988) The pattern of dendritic development in the cerebral cortex of the rat. Dev Brain Res 41:209-219.

Prochiantz A, Delacourte A, Daguet M-C, Paulin D (1982) Intermediate filament proteins in mouse brain cells cultured in the presence or absence of fetal calf serum. Exp Cell Res 139:404-410.

Prochiant7. A, Rousselet A, Chamak B (1990) Adhesion and the in vitro development of axons and dendrites. Prog Brain Res 86:331336.

Qian J, Bull MS, Levitt P (1992) Target-derived astroglia regulate axonal outgrowth in a region-specific manner. Dev Biol 149:278-294.

Raff MC (1989) Glial cell diversification in the rat optic nerve. Science 243: 1450-1455

Rossino P, Gavazzi I, Timpl R, Aumailley M, Abbadini M, Giancotti F. Silengo L, Marchisio PC, Tarone G (1990) Nerve growth factor induces increased expression of a laminin binding integrin in rat pheochromocytoma PC12 cells. Exp Cell Res 189:100-108.

Rotwein P, Burgess SK, Milbrandt JD, Krausc JE (1988) Differential expression of insulin-like growth factor genes in rat central nervous system. Proc Natl Acad Sci USA 85:265-269.

Rousselet A, Fetler L, Chamak B, Prochiantz A (1988) Rat mesencephalic neurons in culture exhibit different morphological traits in the presence of media conditioned on mesencephalic or striatal astroglia. Dev Biol 129:495-504.

Rousselet A, Autillo-Touati A, Araus D, Prochiantz A (1990) In vitro 
regulation of neuronal morphogenesis and polarity by astrocyte-derived factors. Dev Biol 137:33-45.

Rubel EW, Smith ZDJ, Steward O (1981) Sprouting in the avian brainstem auditory pathway: dependence on dendritic integrity. $J$ Comp Neurol 202:397-414.

Saad B, Constam DB, Ortmann R, Moos M, Fontana A, Schachner M (1991) Astrocyte-derived TGF-b2 and NGF differentially regulate neural recognition molecule expression by cultured astrocytes. J Cell Biol 115:473-484.

Schilling K, Dickinson MH, Connor JA, Morgan JI (1991) Electrica activity in cerebellar cultures determines Purkinje cell dendritic growth patterns. Neuron 7:891-902.

Scil FJ, Eckenstcin FP, Rcicr PJ (1992) Induction of dendritic spine proliferation by an astrocyte secreted factor. Exp Neurol 117:85-89.

Seilheimer B, Schachner M (1987) Regulation of neural cell adhesion molecule expression on cultured mouse Schwann cells by nerve growth factor. EMBO J 6:1611-1616.

Smith GM, Miller RH, Silver J (1986) Changing role of forebrain astrocytes during development, regenerative failure and induced regeneration upon transplantation. J Comp Neurol 251:23-43.

Smith GM, Rutishouser Y, Silver J, Miller RH (1990) Maturation of astrocytes in vitro alters the extent and molecular basis of neurite outgrowth. Dev Biol 138:377-390.

Thiery JP, Boyer B (1992) The junction between cytokines and cell adhesion. Curr Opin Cell Biol 4:782-792.

Tomaselli KJ, Reichardt LF, Bixby JL (1986) Distinct molecular interactions mediatc ncuronal process outgrowth on non-ncuronal cell surfaces and extracellular matrices. J Cell Biol 103:2659-2672.

Tomaselli K, Neugebauer KM, Bixby JL, Liliei J, Reichardt LF (1988) $\mathrm{N}$-cadrerin and integrins: two receptor systems that mediate neuronal process outgrowth on astrocyte surfaces. Neuron 1:33-43.

Tropea M, Johnson MI, Higgins D (1988) Glial cells promote dendritic development in rat sympathetic neurons in vitro. Glia 1:380-392.
Vickland H, Westrum LE, Kott JN, Patterson SL, Bothwell MA (1991) Nerve growth factor receptor expression in the young and adult rat olfactory system. Brain Res 565:269-279.

Walicke P, Cowan WM, Ueno N, Baird A, Guillemin R (1986) Fibroblast growth factor promotes survival of dissociated hippocampal neurons and enhances neurite extension. Proc Natl Acad Sci USA 83:3012-3016.

Wesselingh SL, Gough NM, Finlay-Jones JJ, McDonald PJ (1990) Detection of cytokine mRNA in astrocyte cultures using the polymerase chain reaction. I ymph Res 9:177-185.

Wise SP, Fleshman JW, Jones EG (1979) Maturation of pyramidal cell form in relation to developing afferent and efferent connections of rat somatic sensory cortex. Neuroscience 4:1275-1297.

Woodward WR, Nishi R, Meshul CK, Williams TE, Coulombe M, Eckenstein FP (1992) Nuclear and cytoplasmic localization of basic fibroblast growth factor in astrocytes and CA2 hippocampal neurons. $\mathrm{J}$ Neurosci 12:142-152.

Yayon A, Lagsbrun M, Esko JD, Leder P, Ornits DM (1991) Cell surface, heparin-like molecules are required for binding of basic fibroblast growth factor to its high affinity receptor. Cell 64:841-848.

Yeh H-J, Ruit KC, Wang Y-X, Parks WC, Snider WD, Deuel TF (1991) PDGF A-chain gene is expressed by mammalian neurons during development and in maturity. Cell 64:209-216.

Yoshida K, Gage F (1991) Fibroblast growth factors stimulate nerve growth factor synthesis and secretion by astrocytes. Brain Res 538: $118-126$

Zafra F, Lindholm D, Castrén E, Hartikka J, Thoenen H (1992) Regulation of brain-derived neurotrophic factor and nerve growth factor mRNA in primary cultures of hippocampal neurons and astrocytes. J Neurosci 12:4793-4799. 